\title{
Green nanotechnology-based drug delivery systems for osteogenic disorders
}

David Medina-Cruz ${ }^{1}$,, Ebrahim Mostafavi ${ }^{1},{ }^{*}$, Ada Vernet-Crua ${ }^{1}$, Junjiang Cheng ${ }^{1}$, Veer Shaha ${ }^{1}$, Jorge Luis Cholula-Diaz ${ }^{2}$, Gregory Guisbiers ${ }^{3}$, Juan Tao ${ }^{1}$, Jose Miguel Garcia-Martin ${ }^{4}$, and Thomas J. Webster ${ }^{1}$

*These authors contributed equally to this article

1. Department of Chemical Engineering, Northeastern University, Boston, MA, 02115, USA

2. School of Engineering and Sciences, Tecnologico de Monterrey, Av. Eugenio Garza Sada 2501, Monterrey, NL 64849, Mexico

3. Department of Physics and Astronomy, University of Arkansas at Little Rock, Little Rock, AR, 72204, USA

4. Instituto de Micro y Nanotecnología, IMN-CNM, CSIC, Isaac Newton 8, 28760 Tres Cantos, Madrid, Spain 


\begin{abstract}
Introduction: Current treatments for osteogenic disorders are often successful, however they are not free of drawbacks, such as toxicity or side effects. Nanotechnology offers a platform for drug delivery in the treatment of bone disorders, which can overcome such limitations. Nevertheless, traditional synthesis of nanomaterials presents environmental and health concerns due to its production of toxic by-products, the need for extreme and harsh raw materials, and their lack of biocompatibility over time.

Areas covered: This review article contains an overview of the current status of treating osteogenic disorders employing green nanotechnological approaches, showing some of the latest advances in the application of green nanomaterials, as drug delivery carriers, for the effective treatment of osteogenic disorders.

Expert opinion: Green nanotechnology as a potential solution, understood as the use of living organisms, biomolecules and environmentally friendly processes for the production of nanomaterials. Nanomaterials derived from bacterial cultures or biomolecules isolated from living organisms, such as carbohydrates, proteins, and nucleic acids, have been proven to be effective composites. These nanomaterials introduce enhancements in the treatment and prevention of osteogenic disorders, compared to physiochemicallysynthesized nanostructures, specifically in terms of their improved cell attachment and proliferation, as well as their ability to prevent bacterial adhesion.
\end{abstract}

Keywords: nanotechnology; osteogenic disorders; green nanotechnology; nanomedicine; drug delivery systems; bone tissue regeneration; controlled release; targeted delivery; bone disorders; nano-engineered scaffolds; nanoparticles 


\section{Acronyms}

Alkaline phosphatase (ALP); Bone morphogenic protein-2 (BMP2); bone marrow stromal cells (BMSCs); Bone marrow-derived mesenchymal stem cells (BMMSCs); Bone morphogenetic protein 2 (BMP2); Bone morphogenetic protein 7 (BMP7); Calcium Phosphate (CP); Carboxymethyl chitosan (CMCS); Cholesteryl-group and acryloyl group-bearing pullulan (CHPOA); Deferoxamine (DFO); Deoxyribonucleic acid (DNA); Fibroblast growth factor-2 (FGF2); Mouse osteoblast cell line (MC3T3E1); Nano-hydroxyapatite (nHA); Nanomaterials (NMs); Nanoparticles (NPs); Titanium (Ti); Silk sericin (SS)

Article highlights box

- Drug delivery for the treatment of osteogenic disorders is not free of drawbacks

- Nanotechnology offers a suitable solution to overcome such inconveniences

- Traditional synthesis of nanomaterials have problems related to their biomedical applicability

- Green nanotechnology appears as a potential solution through the use of environmentally-friendly and naturally-derived approaches

- Green-derived nanotechnologies show enhanced biocompatibility and applicability for the drug delivery of compounds to treat osteogenic disorders.

\section{Introduction}

\subsection{The skeletal system and bone tissue}

The skeletal system forms the internal framework of the human body, which is tasked with performing vital functions needed for survival, such as support, movement, protection, blood cell production, calcium storage and endocrine regulations. Along with cartilage, bone is one of the skeletal system's tissues- a dynamic organ that is continuously undergoing remodeling processes, in order to maintain a healthy and life-long execution of essential skeletal functions [1,2]. Therefore, it is vital that the bone adjusts to different mechanical changes by varying environmental conditions. Bone tissue is made of three types of bone cells:- while osteoblasts and osteocytes are actively involved in the formation of bone (mineralization), osteoclasts are tasked with the resorption of bone tissue. A bone is generally classified 
as either cortical or trabecular. While cortical bone is relatively denser, trabecular bone is the primary place of bone remodeling; and hence, trabecular bone is the main site for the appearance of bone disorders $[3,4]$.

\subsection{Bone disorders}

Bone disease leads to abnormalities of skeletal system. Typically, bone mass is regulated by bone resorption - a process by which osteoclasts break down the tissue and release the minerals. The very process leads to bone formation, undergoing a systematic remodeling process [5]. Nevertheless, the balance can be altered by several factors, from phenotype to genotype, thus leading to abnormal bone remodeling, and the eventual development of bone disorders (Table 1) [5].

Table 1. Principal bone disorders, symptoms, and currently available treatments

\begin{tabular}{|c|c|c|c|}
\hline $\begin{array}{c}\text { Type of Bone } \\
\text { disorder }\end{array}$ & Facts and details & Symptoms & Treatments \\
\hline Osteoarthritis $[6,7]$ & $\begin{array}{l}\text { Osteoarthritis occurs when the } \\
\text { protective cartilage that } \\
\text { cushions the ends of the bone, } \\
\text { shrinks down over time. }\end{array}$ & $\begin{array}{ll}- & \text { Stiffness } \\
- & \text { Tenderness } \\
- & \text { Loss of flexibility } \\
- & \text { Grating sensation } \\
- & \text { Bone spurs and swelling } \\
- & \text { Pain }\end{array}$ & $\begin{array}{l}\text { Medication: Acetaminophen, } \\
\text { Nonsteroidal anti-inflammatory } \\
\text { drugs (NSAIDs), Duloxetine } \\
\text { (Cymbalta) } \\
\text { Therapy: Physical and occupational } \\
\text { therapy. } \\
\text { Surgical: cortisone and lubrication } \\
\text { injections, realigning bones and joint } \\
\text { replacement }\end{array}$ \\
\hline Osteoporosis $[8,9]$ & $\begin{array}{l}\text { Osteoporosis happens when } \\
\text { the density of the bone is } \\
\text { reduced, leading to } \\
\text { modification of a tissue, that } \\
\text { is more porous and fragile. }\end{array}$ & $\begin{array}{ll}\text { - } & \text { Back pain (collapsed vertebra) } \\
\text { - } & \text { Loss of height over time } \\
\text { - } & \text { Easily breaking bones }\end{array}$ & $\begin{array}{l}\text { Medication: Alendronate } \\
\text { (Fosamax), Risedronate (Actonel), } \\
\text { Ibandronate (Boniva), Zoledronic } \\
\text { acid (Reclast), Teriparatide } \\
\text { (Forteo), Denosumab (Prolia, } \\
\text { Xgeva), Abaloparatide (Tymlos) }\end{array}$ \\
\hline $\begin{array}{c}\text { Osteomyelitis } \\
{[10,11]}\end{array}$ & $\begin{array}{l}\text { Osteomyelitis is an infection, } \\
\text { which can reach a bone by } \\
\text { moving through the } \\
\text { bloodstream or spreading } \\
\text { from nearby tissue. }\end{array}$ & $\begin{array}{ll}\text { - } & \text { Fever } \\
\text { - } & \text { Swelling, } \\
\text { - } & \text { Warmth in the area } \\
\text { - } & \text { Pain in the area } \\
\text { - } & \text { Fatigue }\end{array}$ & $\begin{array}{l}\text { Medication: antibiotics } \\
\text { Surgical: drain infected areas, } \\
\text { remove diseased bone and tissue, } \\
\text { restore blood flow to the bone, } \\
\text { remove any foreign objects and } \\
\text { amputate of limbs }\end{array}$ \\
\hline
\end{tabular}




\begin{tabular}{|c|c|c|c|}
\hline $\begin{array}{c}\text { Osteosarcoma } \\
{[12,13]}\end{array}$ & $\begin{array}{l}\text { Osteosarcoma is the most } \\
\text { frequent type of bone cancer, } \\
\text { which is most often localized } \\
\text { in the longer bones within the } \\
\text { skeletal system. }\end{array}$ & $\begin{array}{ll}\text { - } & \text { Swelling near a bone } \\
\text { - } & \text { Bone and joint pain } \\
\text { - } & \text { Bone injury } \\
& \text { Bone break without reason }\end{array}$ & $\begin{array}{l}\text { Medication: chemotherapy, clinical } \\
\text { trials of medication } \\
\text { Surgical: limb-sparing surgery, } \\
\text { amputation, rotationplasty. } \\
\text { Radiotherapy (only selected cases). }\end{array}$ \\
\hline $\begin{array}{c}\text { Osteogenic } \\
\text { imperfecta } \\
{[14,15]}\end{array}$ & $\begin{array}{l}\text { Osteogenic imperfecta is a } \\
\text { genetic disease characterized } \\
\text { by brittle bones that break } \\
\text { easily. }\end{array}$ & $\begin{array}{ll}\text { - } & \text { Bone deformities } \\
\text { - } & \text { Multiple broken bones } \\
\text { - } & \text { Loose joints } \\
\text { - } & \text { Weak teeth } \\
\text { - } & \text { Blue sclera } \\
& \text { Bowed legs and arms }\end{array}$ & 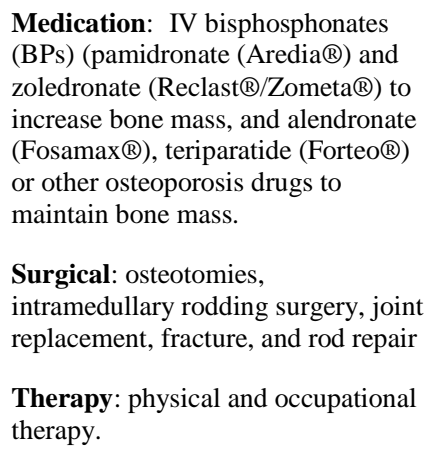 \\
\hline
\end{tabular}

\section{Bone drug delivery systems}

The realm of medical research has been making significant advances in both the prevention and treatment of various bone disorders. Hundreds of different medicinal compounds, surgical, and therapy-based treatments have been developed over time (reference: Table 1). This review is focused on drug delivery systems to treat bone diseases, the reason by which therapy-based and surgical treatments are left out of scope and will not be discussed. A drug delivery system is defined as the technology that serves to transport pharmaceutical compounds in the body as needed, to safely achieve the desired therapeutic effect. In terms of bone, drug delivery systems can be organized in two different groups depending on the targeted tissue: the whole skeletal system, also known as bone-sites, or specific bone cellular locations [16]. Bone-targeting molecules can be either synthetic or biological, and prevent bone-tissue loss and help bone regeneration [17]. These drugs commonly present high stability when they reach the targeted tissue, as well as an affinity for bone mineral at low systemic levels [18]. In this section, different strategies of drug administration to bone tissue are summarized, and organized, in terms of the drugs that are delivered

\section{(Figure 1).}




\subsection{Drug delivery of Bisphosphonates (BPs)}

BPs are one of the most used non-specific chemically-synthesized drugs, derived from inorganic pyrophosphates, phosphorus oxyanions that contain a P-O-P linkage. These Pyrophosphates are natural compounds that regulate bone mineralization by binding to hydroxyapatite (HA) crystals [19]. Due to their high susceptibility for calcium phosphate (CP), BPs are capable of inhibiting bone resorption. Therefore, they have been largely used to treat bone-diseases like osteoporosis or osteogenesis imperfecta [20]. BPs are administrated either by intravenous route every 3-4 weeks, or once daily by oral route [21]. However, there are some alternatives to these administrative approaches. One such example is the microencapsulation of the BPs inside biodegradable poly(lactic-co-glycolic acid) (PLGA). Another example is through the association of its molecules (either in a free or microencapsulated form) to biomaterials, that can be implanted or conjugated (Figure 1A). The systemic administration of BPs commonly results in $20-50 \%$ deposition of the molecule at bone tissues, with minimal accumulation at other sites [22,23].

\subsection{Tetracyclines (TCs)}

TCs are broad-spectrum antibiotics used to treat different bacterial bone diseases [24]. These can be directly isolated from several species of Streptomyces bacteria, or produced semi-synthetically from those isolated compounds; hence, rendering a wide variety of compounds under the same antibiotics' family. TCs inhibit bone resorption, but also stop the action of collagenases in breaking the peptide bonds of collagen, while promoting the generation of osteoblasts [25]. Consequently, TCs have been mostly used to treat periodontitis, which is related to alveolar bone loss [26]. TCs are administered both systematically and also as local drug delivery agent. which serve as an advantage for avoiding the harmful effect of systemic administration. These effects include the development of antibiotic resistant flora and suppression of the normal flora [27]. Successful local drug delivery methods are based on the combination of TCs with fibers [28] or bioactive glass [29]. This combination acts as a bioactive behavior, 
as well as the encapsulation of TCs within PLGA [30] or PEG-PLGA micelles [31], allowing for a controlled released of the compounds within the infected targeted area.

\subsection{Oligopeptides}

Oligopeptides are small sequences of amino acids, naturally present in the human body, which have the ability to link to HA when aspartic acid (Asp) and glutamic acid (Glu) residues are present in their structure, preventing bone resorption [32,33]. Osteopontin and bone sialoprotein are two major noncollagenous proteins in the bone, which have both L-Asp and L-Glu repetitive sequences in their structure, respectively, aiding the process of rapid binding to HA once secreted in osteoblastic cell culture. Thus, these oligopeptides are suitable candidates as bone-targeting agents that can be combined with different drugs (Figure 1B). For instance, after systemic administration, a drug tagged with an oligopeptide can be selectively delivered to bind with bone, acting as the active drug which is gradually released during the bone remodeling processes [34-36].

\subsection{Aptamers}

Nucleic acid aptamers are short, single-stranded deoxyribonucleic acid (DNA), or ribonucleic acid (RNA) molecules that are selected for binding to a specific target [37]. Aptamers are considered chemical antibodies because they are functionally comparable to traditional antibodies. However, they present several improvements, in terms of their mechanical and chemical properties. Aptamers are extremely selective and specific to target recognition and binding. Furthermore, they are relatively small and possess flexible structure, together with a quick chemical production, easy chemical modification, high stability, and lack of immunogenicity. In addition, many aptamers can be internalized upon binding to cellular receptors, making them effective targeted delivery agents for small interfering RNA (siRNAs), microRNAs, and conventional drugs - which are extremely valuable for targeting bone diseases. Various cell-type-specific aptamers have been conjugated with therapeutic agents (such as siRNA, microRNA, chemotherapeutics, or toxins), or delivery vehicles (like organic or inorganic nanocarriers) for targeted 
delivery in a cell-type-specific manner $[37,38]$. A recent proof-of-concept study generated aptamerfunctionalized lipid nanoparticles (LNPs) for siRNA delivery. By using cell-based systematic evolution of ligands by exponential enrichment (SELEX), DNA aptamers targeting osteoblasts were used for decoration of LNPs that encapsulated siRNAs. Then, the delivery system not only facilitated in vivo osteoblast-selective siRNA uptake, but also resulted in gene silencing in vivo. Consequently, this phenomenon aided bone formation and bone microarchitecture, while enhancing the mechanical properties of the new tissue [37,39].
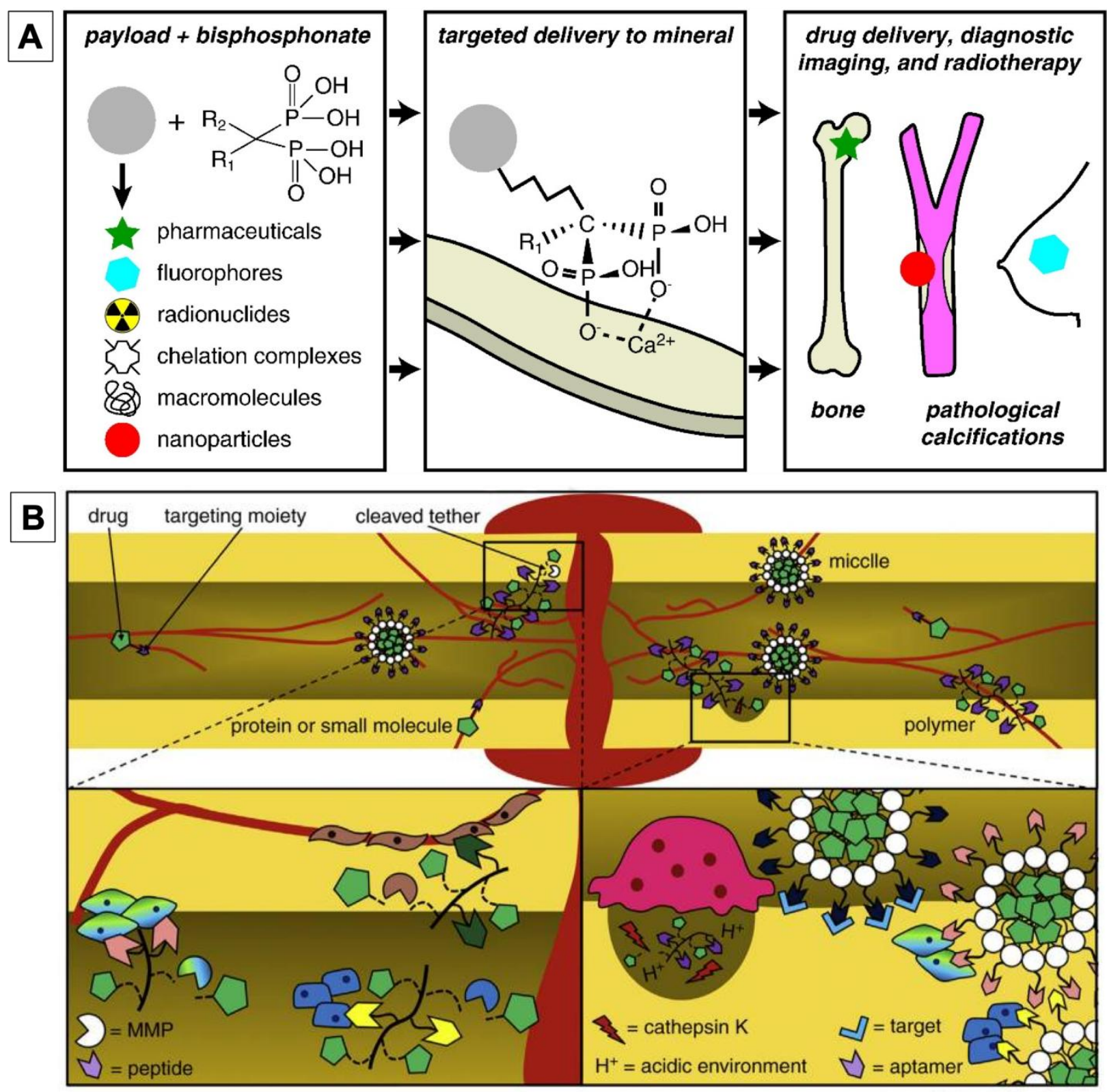
Figure 1. (A) Schematic diagram showing the use of BPs, either alone or conjugated to various pharmaceuticals, fluorophores, radionuclides, chelation complexes, macromolecules, and nanoparticles, for targeting mineral in bone and pathological calcifications for drug delivery, diagnostic imaging, and radiotherapy [22]; (B) Targeted, systemic drug delivery uses targeting moieties (e.g. peptides and aptamers) to deliver drugs to bone. Carriers travel through the bloodstream and exit upon targeting. Drugs are cleaved via matrix metalloproteinases (MMP) and enzymatic activity or due to a change in $\mathrm{pH}$. [38]. MMP = Matrix metalloproteinases

\subsection{Challenges to current drug delivery approaches for bone diseases}

From all the variety of bone disorders, only trauma, osteoporosis, and osteogenic imperfecta cause approximately 6 million fractures in the United States annually. 5-10\% of all fractures result in delayed union or non-union, with age, smoking, and diabetes as common comorbidities of poor healing [38,40]. A successful bone regeneration requires a complex and orchestrated cascade of cells and growth factors, and effective targeting of the drugs in the tissue. While novel drug delivery approaches have yielded different levels of success clinically, there are still significant technological challenges.

For instance, bone disorders often require clinical intervention measures - the outcome of which is not always satisfactory. Some of the most common skeleton disorders have no effective treatments available, while others present a distorted balance between adverse reactions and therapeutic effect. Due to the poor penetration into the bone tissue, systemic drug delivery may result in systemic toxicity [41]. Currently, most of the widely used drugs face major difficulty in reaching the target tissue. Therefore, large doses must be taken, which increases the risk of toxicity [16]. For instance, patients taking antiosteoporotic drugs are exposed to adverse effects such as cancer risks and endometritis due to the higher doses administered [42], hence existing an unmet need for the improvement of more efficient delivery systems with less toxicity.

\section{Nanotechnology as a solution for the treatment of bone disorders}

Acting as a bridge between nanotechnology and human physiology, nanomedicine allows scientists and researchers to study biological systems at the nanoscale with the aim of revolutionizing traditional therapies. This aim is further developed by employing nanomedicine for improving the effectiveness of drug delivery strategies to replicate natural healthy tissues [16]. The emergence of nanotechnology has set 
high expectations in understanding the complexities and difficulties in medicine and biological science. The application of nanomaterials (NMs) in medicine has led to the continuous rise of nanomedicine, with great potential in the treatment of several diseases, including bone disorders. Therefore, NMs have become a promising treatment for bone disorders, eliminating many pitfalls of the current therapies aforementioned. Employing nanotechnology concepts, advanced drug delivery systems play a vital role in the osteogenic bone disorders, and promise for enhancing the repair of degenerated and injured tissues [43,44]. Tables 2 and 3 summarize the most commonly used nanotechnology-based systems and their targeting strategies for bone drug delivery, including polymeric moieties nanoparticles (NPs) as drug carriers, nano-based-loading methods and hydrogel-based release, among others. Many of the components in bone tissue are at the nanometer scale, self-assembled, nanostructured extracellular matrix (ECM) substrates, which can closely surround, interact, and affect bone-forming cells, along with promoting their adhesion, proliferation, and differentiation (Figure 2) [45,46]. Literature flourish with NMs-based targeting drug delivery systems have improved bone regeneration because of their small size allowing them to traverse biological barriers for more efficient delivery $[47,48]$.

The principle behind nanotechnology-based drug delivery, as a treatment modality, begins with the creation of drug-loaded NPs (Figure 2A)., which provides a promising approach for prolonging the circulation time, and improving the biodistribution of drugs [49]. NPs can be easily implemented (on an individual basis) during the operative surgery on an injured bone site. These NPs can also play a crucial role as therapeutic delivery agent, or can be incorporated into a nanoengineered biomaterial (Figures 2B and Table 3), such as an electrospun support (Figures 2C), or hydrogel (Figure 2D) to accelerate the bone regeneration mechanism. During the last few years, researchers also employed a combinatorial nano-based approach proving a synergistic effect for both the therapeutic deliveries and the regeneration of the tissue [50] (Figure 2B). In the context of bone disorders, NMs can provide scaffolds with exceptional tissue regeneration via mechanical stimulation. This mechanism releases various loaded drugs 
and mediators, or 3D scaffolds, for cell growth and differentiation of bone marrow stem cells to osteocytes [44]

The efficient targeted delivery of bone-specific drugs to the desired site of action can increase efficacy, and reduce toxicity in all kind of osteogenic disorders. However, disadvantages include delivering the drug to the target without losing functionality, as well as avoiding some kind of adverse side effects [16].

Consequently, one of most critical problems with NMs-based drug delivery approaches is the production of the delivery vehicles. Traditional synthesis of NMs relies upon physicochemical processes, which are hindered by several drawbacks - such as harsh processing conditions, production and release of toxic byproducts or lack of a desired biocompatibility - leading to unwanted cytotoxic profiles upon contact with biological tissue [51-53]. Furthermore, unique instrumentation is often required for the production of the carriers, such as chemical vapor deposition (CVD) chambers or ultra-high vacuum systems. Additional drawbacks are observed during the aggregation of NPs after synthesis, which can impede both the purification and characterization of the systems, as well as compromise the effectiveness of the newlysynthesized NMs (for biomedical applications) [54]. As a consequence of the synthesis method, some of these NMs might degrade once released in the body, leading to an unwanted production of toxic degradation products that may be harmful to body tissues, or locally lower the $\mathrm{pH}$. As a consequence, using these materials in large dose, could prove defiant. Moreover, due to the complexity of bone tissue, most of the drug delivery systems exhibit poor targeting efficiency and uncontrolled drug release. Therefore, to increase the efficiency of therapy and improve its biomedical outcomes, new targeted drug delivery systems have been intensively pushed forward as potential strategies, avoiding the limitations aforementioned. 


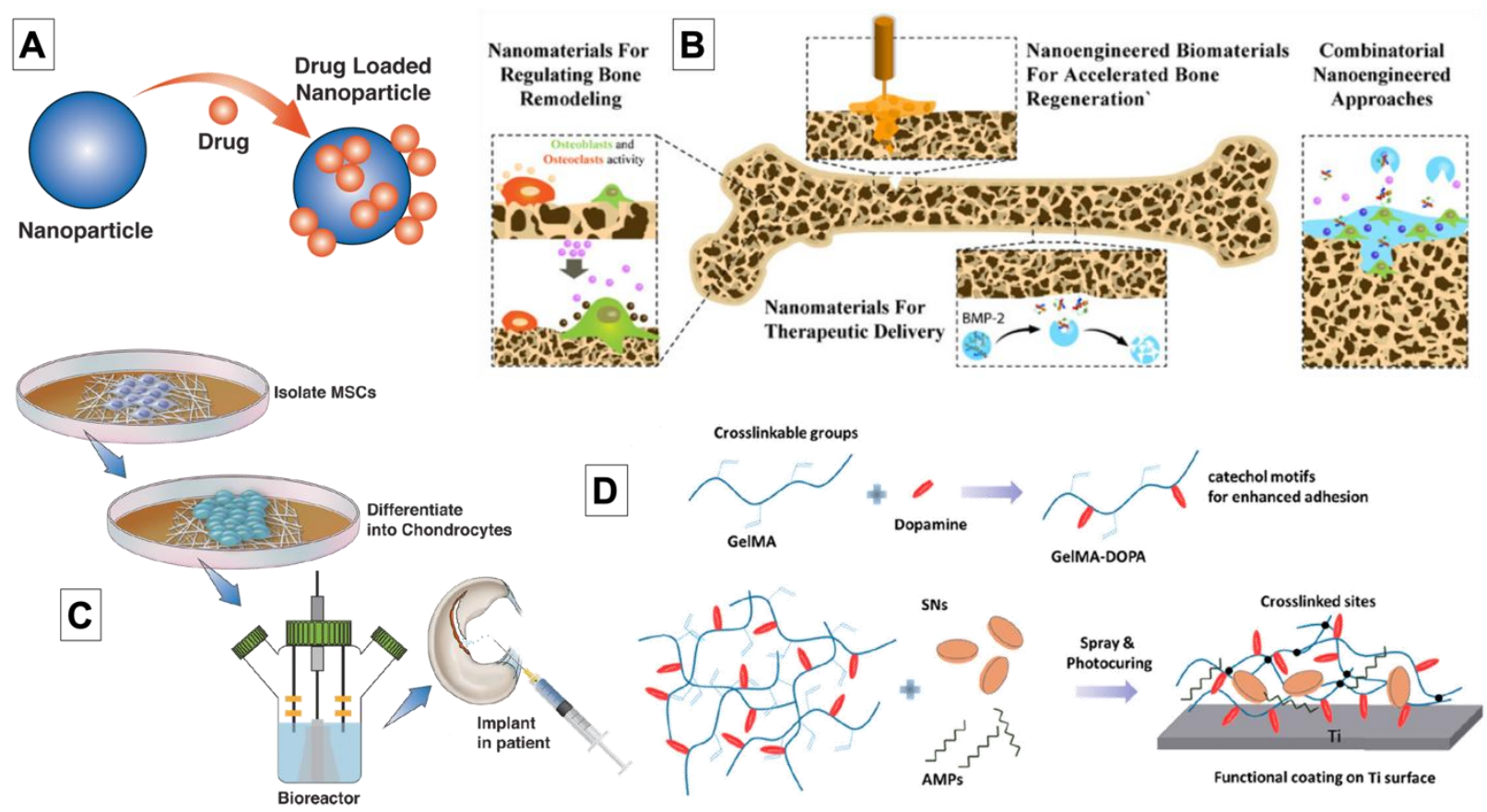

Figure 2. (A) Schematic demonstrating the fundamental principle of drug delivery using nanoparticles[55] This method not only allows for more precise drug targeting but also for greater control of drug release in treating bone diseases. (B) Uses of nanotechnology in the treatment of osteoporotic bone, including nanomaterials for therapeutic delivery, nanomaterials for regulating bone remodeling, nanoengineered biomaterials for accelerated bone regeneration, and combinatorial nanoengineered approaches[50], (C) Regenerative technique using human mesenchymal stem cells (MSCs) to treat bone disorders, including a sequential process of growth, differentiation, and proliferation of the cells onto the desired electrospun scaffold and then implantation inside a bioreactor, followed by reimplanted into the patient [55], (D) Schematic illustration of the formation of a highly adhesive, multifunctional hydrogel coating on titanium (Ti) surfaces [56]

Table 2. Nanoparticle-based drug delivery systems for bone disorders

\begin{tabular}{|c|c|c|c|}
\hline \multicolumn{2}{|c|}{ Type of nanocarrier } & Application & About \\
\hline \multirow{3}{*}{ Polymeric moieties } & BPs & $\begin{array}{l}\text { - } \quad \text { Treating osteoporosis } \\
\quad \text { Mineral-based therapeutics }\end{array}$ & 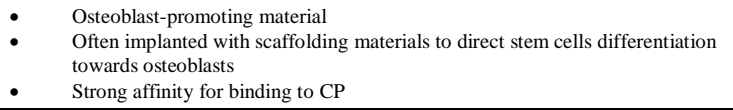 \\
\hline & CPs & $\begin{array}{l}\text { - Gene delivery and gene } \\
\text { therapy }\end{array}$ & $\begin{array}{l}\text { - Superior biocompatibility, biodegradability, and the similarity in structure to } \\
\text { the inorganic composition of bone minerals [56] } \\
\text { CPs can stabilize DNA or RNA through electrostatic interactions } \\
\text { - } \quad \text { Prevent the degradation of nucleotides } \\
\text { Promote the internalization of the former into cells [56] } \\
\text { - Disadvantage: their spontaneous aggregation can result in reduced transfection } \\
\text { efficiency } \\
\text { Gene therapy applications }\end{array}$ \\
\hline & HA & - $\quad$ Mineral-based therapeutics & $\begin{array}{l} \\
\text { Osteoblast-promoting calcium-based materials } \\
\text { Showing an efficient synergistic effect when combining with an osteoclast- } \\
\text { inhibiting BPs [57] }\end{array}$ \\
\hline Inorganic NMs & Gold (Au) NPs & $\begin{array}{l}\text { - Induce osteogenic } \\
\text { differentiation for the } \\
\text { treatment of osteoporosis } \\
\text { Promote homeostasis in } \\
\text { bone remodeling [58] }\end{array}$ & $\begin{array}{l}\text { - Easy to functionalize with drugs, target moieties, and polymers because of } \\
\text { gold-thiol bonds [59] } \\
\text { Intrinsic ability to upregulate osteoblast activity }[58,60] \text { and downregulate } \\
\text { osteoclast differentiation [61] }\end{array}$ \\
\hline
\end{tabular}




\begin{tabular}{|c|c|c|c|}
\hline & Selenium (Se) NPs & $\begin{array}{l}\text { Osteoporosis treatment } \\
\text { while fighting cancer }\end{array}$ & $\begin{array}{l}\text { - } \quad \text { Naturally exists element in the human body } \\
\text { Reduce different types of cancer [62] } \\
\text { Biocompatibility and anti-carcinogenic effects [63] } \\
\text { Increasing the growth of healthy osteoblasts while inhibiting the growth of } \\
\text { cancerous osteoblast }\end{array}$ \\
\hline & Ti nanotubes & $\begin{array}{l}\text { Fabrication of bone } \\
\text { implants in the form of } \\
\text { screws, plates, and pins }\end{array}$ & $\begin{array}{l}\text { - High biocompatibility, and resistance to corrosion [64] } \\
\text { The nano features surface roughness of Ti implants can increase the interaction } \\
\text { with the surface adherent cells and, thus, to promote osseointegration [65] } \\
\text { Toxicity issue at high doses [66] }\end{array}$ \\
\hline & $\begin{array}{l}\text { Superparamagnetic iron } \\
\text { oxide }(\mathrm{Fe} 3 \mathrm{O} 4) \text { NPs }\end{array}$ & $\begin{array}{ll}\text { - } & \text { Magnetic resonance } \\
\text { imaging (MRI) } \\
\text { - } \quad \text { Hyperthermia treatment }\end{array}$ & $\begin{array}{l}\text { - } \quad \text { Magnetic functionality for potential direction in vivo to osteoporotic bone [67] } \\
\text { - } \quad \text { Local delivery [68] } \\
\quad \text { A promising candidate for arthritis imaging through MRI }\end{array}$ \\
\hline & $\begin{array}{l}\text { Mesoporous silica NPs } \\
\text { (MSNPs) }\end{array}$ & - $\quad$ Treatment of osteoporosis & $\begin{array}{l}\text { - Mesoporous structure (up to } 10-20 \mathrm{~nm} \text { pore size) [69] provides high surface } \\
\text { area for efficient drug loading [70] } \\
\text { They can act as both a drug carrier [71] and a bone bioactive agent [72] } \\
\text { Enhance the in vitro osteoconductivity of the nanomaterial when implanted on } \\
\text { Ti [73] }\end{array}$ \\
\hline & Silver (Ag) NPs & $\begin{array}{l}\text { - Antimicrobial nanophase } \\
\text { on orthopedic implants }\end{array}$ & $\begin{array}{ll}\text { - } & \text { Decrease the bacterial colonization on coated Ti implants [74] } \\
\text { - } & \text { Inhibit biofilm formation } \\
& \text { Non-antibiotic-based nanotechnology }\end{array}$ \\
\hline & Tellurium (Te) NPs & $\begin{array}{l}\text { - Antimicrobial coating for } \\
\text { bone implants }\end{array}$ & $\begin{array}{l}\text { Enhancement of antimicrobial properties of the implantable surface } \\
\text { Improvement of osteoblasts proliferation over the surface [75] }\end{array}$ \\
\hline \multirow{6}{*}{ Organic NMs } & Lipid NPs & $\begin{array}{l}\text { Promote increased drug } \\
\text { storage }\end{array}$ & $\begin{array}{l}\text { - } \quad \text { Rigid, uniform nanocarriers can be formed into a core-shell or homogenous } \\
\text { particle structure [47] } \\
\text { Because of their nanoscale, they are an effective tool for the delivery of nucleic } \\
\text { acids for in vivo gene therapy } \\
\text { - Superior biocompatibility, kinetic and physical stability [76] }\end{array}$ \\
\hline & Dendrimers & $\begin{array}{l}\text { Effective delivery of } \\
\text { therapeutic drugs } \\
\text { Gene therapy }\end{array}$ & $\begin{array}{l}\text { - To improve the hydrophilicity and to accelerate cell capture and antibody } \\
\text { conjugation [77,78] } \\
\text { - } \quad \text { Rapid targeting and efficient capturing of tumor cells }\end{array}$ \\
\hline & Micelles & $\begin{array}{l}\text { - Local and specific delivery } \\
\text { of drugs for osteoporosis } \\
\text { treatment [79] }\end{array}$ & $\begin{array}{l}\text { - } \quad \text { Sizes about } 50-100 \mathrm{~nm} \\
\text { - } \\
\text { - }\end{array}$ \\
\hline & Liposomes & $\begin{array}{l}\text { - Treatment of osteoporosis } \\
{[80]}\end{array}$ & $\begin{array}{ll}\text { - } & \text { Hydrophilic material } \\
\text { - } & \text { Inhibition of cell growth } \\
\text { - } & \text { Decreased metastasis } \\
& \text { To incorporate anti-infection in joint replacements [81] }\end{array}$ \\
\hline & Chitosan & $\begin{array}{ll}- & \text { Effective gene carriers } \\
- & \text { Osteoporosis treatment } \\
- & \text { Bone tissue regeneration }\end{array}$ & $\begin{array}{l}\text { - Disadvantage: must be functionalized before use as an effective gene therapy } \\
\text { vector [82] because of the low cell internalization efficiency [83] }\end{array}$ \\
\hline & PLGA & $\begin{array}{l}\text { The delivery of bone- } \\
\text { related hormones and } \\
\text { proteins [84] } \\
\text { Treatment of } \\
\text { osteosarcomas [85] }\end{array}$ & $\begin{array}{l}\text { - } \\
\text { kinetics to functionalized with targeting ligands [86] and tunable drug release } \\
\text { - } \quad \text { Low toxicity [87] } \\
\text { Reduce the adverse effects associated with the administration of antiresorptive } \\
\text { drugs }\end{array}$ \\
\hline Composite NMs & $\begin{array}{l}\text { Nanomagnetic liposomes } \\
\text { [88], PLGA-CP [89] }\end{array}$ & $\begin{array}{ll}- & \text { Promoted bone } \\
& \text { regeneration } \\
\text { - } & \text { Multi-purpose therapy }\end{array}$ & $\begin{array}{l}\text { Enhances new bone formation while preserving the binding sites for osteogenic } \\
\text { differentiation and new bone growth } \\
\text { Multifunctional nanocarrier systems }\end{array}$ \\
\hline
\end{tabular}


Table 3. Nano-engineered scaffolds-based drug delivery systems for bone disorders

\begin{tabular}{|c|c|c|c|}
\hline \multicolumn{2}{|c|}{ Type of nanocarrier } & Application & About \\
\hline Hydrogels & Nanocomposite hydrogels & $\begin{array}{l}\text { Tissue engineering and } \\
\text { regenerative medicine }\end{array}$ & $\begin{array}{ll}\text { - } & \text { Biocompatibility, hydrophilicity, biodegradability, and tunability are the most } \\
\text { important requirements [90] } \\
\text { - } \\
\text { Injectable delivery } \\
\text { Controlling drug release [91] }\end{array}$ \\
\hline Nanofibers & $\begin{array}{l}\text { Electrospun nanofibrous } \\
\text { scaffolds }\end{array}$ & $\begin{array}{l}\text { Tissue engineering and } \\
\text { regenerative medicine }\end{array}$ & $\begin{array}{l}\text { - Increase the mechanical properties of the matrix in addition to promoting } \\
\text { osteoblast differentiation and proliferation [92] } \\
\text { Supporting cellular functions by mimicking biological micro- and nano- } \\
\text { environments (such as the ECM) } \\
\text { - } \quad \text { Controlling drug release [93] }\end{array}$ \\
\hline $\begin{array}{c}\text { Hybrid/ } \\
\text { Composite scaffolds }\end{array}$ & $\begin{array}{l}\text { PEG or gelatin-based } \\
\text { hydrogels incorporated with } \\
\text { nano-silica or nano- } \\
\text { hydroxyapatite (nHA) }\end{array}$ & $\begin{array}{l}\text { Enhanced tissue repair and } \\
\text { regeneration while controlling } \\
\text { the drug release [94] }\end{array}$ & $\begin{array}{l}\text { Harnessing the osteoconductive potential of nanomaterials } \\
\text { Enhancing new bone formation when implanted within a hydrogel scaffold } \\
\text { incorporated with biochemical cues } \\
\text { Adjusting the drug release kinetics, drug stability, drug transportation, scaffold } \\
\text { degradation, and biocompatibility } \\
\text { Premature field of research and a lot of research need to be done }\end{array}$ \\
\hline & & & \\
\hline
\end{tabular}

\section{Green Nanotechnology as a driven technology for treatments of osteogenic disorders.}

Nanotechnology has been widely recognized as a reliable alternative to face the global challenges that come with the environment and the healthcare systems of a modern society. However, the nanoscale world has its own trials, particularly those related to the production of NMs in a sustainable method. [35,95]. Hence, Green Nanotechnology appeared to be a potential solution upon the application of the 12 principles of green chemistry [96] to the synthesis of NMs. Therefore, Green Nanotechnology has been conceived to target the synthesis of NMs by using living organisms, biomolecules or natural waste materials, following methods that either reduce or eliminate the chemical need for harmful substances, such as solvents, reducing and capping agents [97-99]. In terms of nanomedicine, green-synthesized NMs have exhibited great potential as antimicrobial and anticancer agents. These NMs also possess photoimaging and photothermal therapy components, magnetically responsive drug delivery systems, and biomolecules and complex biological structure nanodetectors [100-102]. Nevertheless, the application of 
green-nanotechnological products in the treatment of bone disorders, is considered a newborn field. Despite of the lack of public knowledge, some promising research trends towards the use of green NMs for diagnosis and therapy of osteogenic disorders is discussed in the subsequent sections, exemplifying the utter focus on improvements in the targeting method compared to their traditionally-synthesized counterparts, and the overall applicability of this novel technology.

The following sections are organized with respect to the biomolecules employed for the production and assemblage of the NMs that are used as drug delivery systems for the treatment of different osteogenic disorders.

\subsection{Polysaccharides-based green nanotechnologies}

Polysaccharides are among the most versatile molecules in nature, widely available with significant biomedical applications' potential, leading to a development of several examples of polysaccharidesbased approaches as drug delivery for the treatment of bone disorders (Table 4).

Heparin is a naturally occurring glycosaminoglycan, a complex polysaccharide containing amino groups, with some attractive biomedical properties. This very property makes heparin-based nanocomplexes important biologically-derived drug delivery vehicles, with high loading and enhance releasing abilities. Liu et al. studied the use of these nanocomplexes for the support of placental growth factor (PIGF) and bone morphogenic protein-2 (BMP2). Three groups of PlGF-2/BMP-2-loaded heparin-N-(2-hydroxyl) propyl-3-trimethyl ammonium chitosan chloride (HTCC) nanocomplexes were prepared, achieving a loading efficiency between 83 to $99 \%$, for all complexes with approximate size of $350 \mathrm{~nm}$. Acting as a "sandwich" or a "double duty" component, Heparin interacted with HTCC to form highly stable and biocompatible polyelectrolyte complexes. In in vitro biological assays, PIGF-2 exhibited osteogenic effects comparable to those of BMP-2, despite its dose being lower than the BMP-2 dose, in a similar experiment. Moreover, the results implied that heparin-based nanocomplexes, encapsulating two GFs have enhanced potential for osteoblast functionality, as the nanostructures trigger a favorable bone cell 
function, signifying promise in the bone regeneration process [103]. Similarly, S. E. Kim et al. studied whether or not the combination of previously undifferentiated bone marrow-derived mesenchymal stem cells (BMMSCs) and BMP-2, delivered via heparin-conjugated PLGA nanoparticles, would allow for bone regeneration in vivo. The amount of heparin conjugated to the NPs was $15.8 \pm 0.4 \mathrm{mg} / \mathrm{g}$ of the structures, with a size below $520 \mathrm{~nm}$. Upon combination with a fibrin gel, the sustained delivery system of the NPs was found to be based on the inherent capacity of heparin to bind to BMP-2. This phenomenon was achieved via electrostatic interactions between heparin's negatively-charged sulfate groups and BMP-2 positively-charged amino acid residue. After characterization, an initial in vitro testing found that the heparin-conjugated NPs were able to release BMP-2 over a 2-week period, which allowed BMMSCs to differentiate toward osteogenic cells, expressing alkaline phosphatase (ALP). A subsequent in vivo testing found that undifferentiated BMMSCs (with BMP-2-loaded NPs) induce far more extensive bone formation than either implantation of BMP-2-loaded HCPNs or osteogenically differentiated BMMSCs .[104]

On the other hand, chitosan, a linear polysaccharide obtained from the hard outer skeleton of shellfish, has found substantial application in drug delivery systems through the combination of different NMs. For instance, Lee et al. developed a double emulsion process, in order to generate PLGA-lovastatin-chitosantetracycline NPs as local delivery device, with size around $107 \mathrm{~nm}$. These properties allowed the subsequent release of TCs and lovastatin, to control local infection and promote bone regeneration in periodontitis. A large amount of TCs were released on the first day of administration, followed by a gradual release until day 14 . This study also showed that high concentrations proved more effective against A. actinomycetemcomitans and $P$. nigrescens through an in vitro model. Since most of the encapsulated molecules were released on the first day (and the TCs were incorporated at the outermost chitosan layer), its release was attributed to basic diffusion. Consequently, using a higher degree of chitosan could prove to prolong the release. In vitro testing indicated that the NPs showed excellent 
biocompatibility, antibacterial activity, and increased ALP activity, all of which significantly elevate new bone formation [105].

Alternatively, a low cost-delivery system, based on the nanoencapsulation of chitosan, dextran, and bovine serum albumin (CH-Dext-BSA) into NPs, was reported by Valente et al. With the aim of improving bone regeneration, this dual drug delivery system combined both protein mediators and cells in the same carrier, . These novel nano and microcarriers improved the protection and transportation of the biomolecules and cells into the target bone tissue, enabling their integration., and consequently, bone tissue repair through in vitro studies. This novel procedure also contemplates the possibility to encapsulate other autologous patient cells that further deposit extracellular matrix and accelerate regenerative processes of different tissues [106]. Similarly, Gaur et al. reported a chitosan NPs-mediated delivery of miR-34a - a tumor-suppressive microRNA that downregulates multiple gene products involved in bone-metastatic prostate cancer (PCa) progression - which inhibited prostate tumor growth and preserved bone integrity, both in vitro and in vivo [107].

Similarly, the possibility of immobilizing BMP2 on a chitosan-grafted titanium substrate (Ti-CS-BMP2) was studied, revealing an enhancement of bone marrow stromal cells (BMSCs) adhesion onto the substrate surface, and inducing their differentiation into osteoblasts. An in vitro study showed that along with an osteoconductive effect, this substrate was able to retain adsorbed BMP2, and was capable of slow release of this growth factor[108]. Similarly, the surfaces of Ti alloy substrates were functionalized by covalently grafting carboxymethyl chitosan (CMCS), followed by the conjugating BMP2 to the CMCSgrafted surface. The CMCS-BMP2 modified substrates were strategized to enhance tissue integration by creating a selective biointeractive surface, that simultaneously enhances bone cell function, while decreasing bacterial adhesion of both Staphylococcus aureus and Staphylococcus epidermidis. An in vitro study revealed a significant promotion of cell attachment, ALP activity, and calcium mineral deposition of both osteoblast and BMSCs [109]. 
Another useful example is found in pullulan - a polysaccharide polymer consisting of maltotriose units. Cholesteryl group and acryloyl group-bearing pullulan (CHPOA) nanogels were prepared to form fastdegradable hydrogels (CHPOA/hydrogels) with an aim to suppress limitations of similar drug delivery vehicles, such as inflammation, poor cost-efficiency, and varying interindividual susceptibility (Figure 3A). Over a longer term period, the novel drug delivery system allowed the controlled release of both BMP2 and recombinant human fibroblast growth factor 18 (FGF18) to the bone defect, in order to induce effective bone repair (Figure 3B). The authors conclusively found that the combination of the CHPOA/hydrogel system with the GFs might be a step towards efficient bone tissue engineering, both in vitro and in vivo. [110].

Gellan xanthan gum is an anionic exocellular polysaccharide derived from the bacteria Sphingomonas elodea. Gellan xanthan gels were combined with chitosan NPs, basic fibroblast growth factor (bFGF), and bone morphogenetic protein 7 (BMP7) in a dual growth factor delivery system, in order to promote the differentiation of human fetal osteoblasts (Figure 3D). The results of an in vitro study concluded that the dual GFs loaded gels showed a higher ALP and calcium deposition, compared to single GFs loaded gels. [111]. The gels also showed antibacterial effects against Pseudomonas aeruginosa, Staphylococcus aureus, and Staphylococcus epidermidis - the common pathogens in a possible implant failure [112,113]

Alternatively, some examples can be found for the use of alginate, a natural anionic polysaccharide polymer collected from brown seaweed, that shows several biomedical applications [114]. . GonzalesFernandez et al. produced gene-activated constructs, in which MSCs and nHA complexed were combined with plasmid DNA (pDNA), encoding for transforming growth factor-beta 3 (pTGF- $\beta 3$ ), bone morphogenetic protein 2 (BMP2), or a combination of both (pTGF-33-BMP2) (which were then encapsulated into alginate hydrogels). The gene-activated alginate hydrogel was studied in vitro and was shown to be capable of supporting nHA-mediated nonviral gene transfer, in order to control the phenotype of mesenchymal stem cells (MSCs), support transfection of encapsulated MSCs, and direct their phenotype toward either a chondrogenic or an osteogenic phenotype [115]. 
Table 4. Different types of polysaccharides-based nanotechnologies for treatment of bone tissue

\begin{tabular}{|c|c|c|c|}
\hline Type of nanosystem & Nanocarriers & Drug delivered & Main features \\
\hline \multirow{9}{*}{ Polysaccharides-based } & $\begin{array}{l}\text { Heparin-based nanocomplexes [103] } \\
\text { Heparin-conjugated PLGA-NPs [104] }\end{array}$ & $\begin{array}{l}\text { PIGF } \\
\text { BMP2 }\end{array}$ & $\begin{array}{l}-\quad \text { High-loading efficiency } \\
\text { - } \quad \text { Enhanced released }\end{array}$ \\
\hline & PLGA-lovastin- chitosan-tetracycline NPs [105] & $\begin{array}{c}\text { TCs } \\
\text { Lovastin }\end{array}$ & $\begin{array}{ll}\text { - } & \text { Sequential drug release } \\
\text { - } & \text { Biocompatibility } \\
\text { - } & \text { ALP activity }\end{array}$ \\
\hline & Chitosan-dextran-bovine serum albumin (CH-Dext-BSA) [106] & $\begin{array}{r}\text { BSA } \\
\text { MSCs }\end{array}$ & $\begin{array}{ll}\text { - } & \text { Dual drug delivery system } \\
\text { - } & \text { Protection of the loaded drug }\end{array}$ \\
\hline & Chitosan-NPs [107] & $\operatorname{miR}-34 a$ & - $\quad$ microRNA delivery \\
\hline & $\begin{array}{l}\text { Chitosan-grafted Ti substrate embedded with bone morphogenetic protein-2 (Ti- } \\
\qquad \text { CS-BMP2) [108] }\end{array}$ & BMP2 & $\begin{array}{l}\text { - } \\
\text { - } \\
\text { Effective control of the drug release }\end{array}$ \\
\hline & Ti-Carboxymethyl chitosan (CMCS) conjugated to BMP2 (CMCS-BMP2) [109] & BMP2 & $\begin{array}{ll}\text { - } & \text { Cell attachment promotion } \\
\text { - } & \text { ALP activity } \\
\text { - } & \text { Calcium mineral deposition }\end{array}$ \\
\hline & Cholesteryl group- and acryloyl group-bearing pullulan (CHPOA) nanogels [110] & $\begin{array}{l}\text { BMP2 } \\
\text { FGF18 }\end{array}$ & - Controlled release of proteins \\
\hline & Gellan xanthan gels combined with chitosan NPs, bFGF and BMP7 [111] & $\begin{array}{l}\text { bFGF } \\
\text { BMP7 }\end{array}$ & $\begin{array}{ll}\text { - } & \text { Dual growth factor delivery system } \\
\text { - } & \text { Cell differentiation promotion } \\
\text { - } & \text { Antibacterial activity }\end{array}$ \\
\hline & Alginate hydrogels combined with nHA [115] & $\begin{array}{c}\text { TGF- } \beta 3 \\
\text { BMP2 }\end{array}$ & - Cell phenotype control \\
\hline
\end{tabular}

\subsection{Protein-based green nanotechnologies}

Protein-based nanotechnology is an emerging field that is focused on the use of biologically-derived proteins as raw materials for the production and functionalization of nanostructures with biomedical applications. Despite being a relatively new field, several examples of the use of these biomolecules, as drug delivery carriers, have been developed (and tested) in the last few years (Table 5).

Silk sericin (SS) is a glycoprotein created by bombyx mori silkworms during the production of silk, with a variable aminoacid composition and diverse functional groups. These characteristics confer attractive bioactive properties, which are particularly interesting for biomedical applications, including bone repair. Therefore, SS has been used in different formulations, such as films, gels or sponges, as biologically- 
derived drug delivery vehicles of different molecules [116]. For instance, Nishida's group evaluated the practical applicability of SS films in the effective repair of defective tissues, with fibroblast growth factor2 (FGF2) incorporated into films, and later implanted on skull defects in rats. Through enzymatic hydrolysis in vivo, these films successfully released FGF2 in a prolonged and sustained manner. Since these films supported the growth of tissues around skull wounds in rats, their potential use for the acceleration of bone remodeling and wound healing was encouraged[117]. An intriguing bone tissue engineering approach showed chitosan, $\beta$-glycerophosphate ( $\beta$-GP), and SS hydrogels being loaded with longan seed extract (LE), exhibiting an irregular pore structure. The incorporation of SS affected the network structure of the hydrogels, leading to a rapid degradation. Moreover, when loaded with LE, the cumulative amounts of both gallic acid (GA) and ellagic acid (EA) released from the hydrogels increased with an increase in the SS content. Finally, these thermosensitive hydrogels were non-toxic to both a mouse fibroblast cell line (NCTC clone 929) and a mouse osteoblast cell line (MC3T3-E1). As evident from the in vitro results the attachment of MC3T3-E1 cells to the surface of the hydrogels was also promoted. [118].

Collagen is a natural protein, which hosts amino acids, organized in triple-helices of elongated fibrils, allowing for an accelerated bone regeneration, through the use of different formulations. For example, a quick bone defect regeneration can be easily achieved through the use of a bioactive collagen nHA scaffold, engineered specifically for bone repair. This nHA scaffold can sustain localized delivery of BMP2 and vascular endothelial growth factor (pVEGF), pro-osteogenic and pro-angiogenic genes respectively, by using a non-viral dual delivery system [119]. The authors have shown the therapeutic efficacy of using non-viral vectors in a 3D scaffold, both in vitro and [within a critical-size defect] in vivo. After only 4 weeks, rats treated with the nHA dual scaffold displayed complete bridging of the defect, increasing bone regeneration and markedly accelerating bone healing.

Gelatin is a mixture of peptides, produced by partial hydrolysis of collagen, extracted from the skin, bones, and connective tissues of animals. Gelatin has shown potential as an integral component of a drug 
delivery system (Figure 3C). For instance, Raina et al. developed a novel macroporous composite biomaterial, consisting of gelatin, HA and calcium sulfate for co-delivery of bone morphogenic protein-2 (rhBMP2) and zoledronic acid (ZA). The authors hypothesized that the biomaterial mimics the structure of trabecular bone, and thereby constitutes a better scaffolding system in terms of its osteoconductivity. It effectively induces osteogenic differentiation of osteoblast precursor MC3T3-e1 cells by significantly increasing the biochemical and genetic markers of osteoblastic differentiation. In vitro results clearly showed that a low amount of rhBMP-2 was released, contrary to the in vivo results, wherein nearly $65 \%$ of the protein was released in a controlled manner over a period of 4 weeks. Similar results were obtained with the ZA release experimentation. Consequently, this fabricated biomaterial proved to be an efficient carrier device for the co-delivery of both molecules, with further potential for reducing the doses of rhBMP- 2 and ZA, in order to achieve similar results [120].

Table 5. Different types of protein-based nanotechnologies for treatment of bone tissue

\begin{tabular}{|c|c|c|c|}
\hline Type of nanosystem & Nanocarriers & Drug delivered & Main features \\
\hline \multirow{4}{*}{ Protein-based } & SS films [117] & FGF2 & - $\quad$ Drug release control \\
\hline & $\begin{array}{c}\text { Chitosan, } \beta \text {-glycerophosphate and } \\
\text { SS hydrogels }\end{array}$ & $\begin{array}{l}\text { Longan seed extract (LE) } \\
\text { gallic acid (GA), ellagic acid (EA) }\end{array}$ & - Drug release control \\
\hline & $\begin{array}{l}\text { Bioactive collagen nHA scaffold } \\
\qquad[119]\end{array}$ & $\begin{array}{l}\text { BMP2 } \\
\text { pVEGF }\end{array}$ & $\begin{array}{l}\text { - Localized delivery of both an } \\
\text { angiogenic and an osteogenic gene }\end{array}$ \\
\hline & Gelatin-HA-calcium sulphate [120] & $\begin{array}{l}\text { rhBMP2 } \\
\text { ZA }\end{array}$ & - Osteogenic differentiation \\
\hline
\end{tabular}

\subsection{Calcium-based green nanotechnologies}


$\mathrm{CP}$ is a natural bone mineral, with the form of a carbonated apatite. Like HA, CP can be combined with some green nanotechnologies, leading to outstanding improvements for the management of bone-derived problems. as well as for developing drug delivery systems (Table 6).

For instance, an unusual approach was proposed by Gonzalez-McQuire et al. for the preparation of CPcoated human mesenchymal cells (MSCs) by addition of bio-functionalized HA colloids (Figure 3D). This led to the promotion of osteoblastic differentiation in the absence of growth factors, enhanced rates of gene transfection in osteosarcoma bone cells, as well as low, but promising, transfection efficiencies in primary bone marrow stromal cells. The coated cells remained viable as living biocomposites, wherein cell activity was effectively stimulated by the modular amalgamation of the composite, rather than by exogenous substrates or media. Besides, the flexibility of this approach promised for a simple methodology to control the development of multiple cell lineages from common precursors both ex vivo, while enhancing cryopreservation of the MSCs in vivo [121]. Similarly, Yang et al. showed that $100 \mathrm{~nm}$ DNA-loaded NPs could protect the DNA encapsulated inside from external DNase, and release the loaded DNA in a low-acid environment. Experiments in vitro confirmed an effective NPs transfection - both accelerating and promoting the odontogenic differentiation of rat dental pulp stem cells (when cultured in the 3D scaffolds). This phenomenon confirms that the plasmid DNA-loaded CP-NPs were an effective non-viral vector for gene delivery, and that they functioned well for odontogenic differentiation through BMP2 transfection [122]. Alternatively, a recent study revealed that $10 \%$ of iron (Fe) could be isomorphously doped into the HA nanoparticles, rendering a biomaterial with excellent antibacterial properties, enhanced biocompatibility, and bioactivity. This allows for a controlled and sustained drug release of the iron inclusion. In vitro investigations indicated the enhanced biocompatibility and strengthened ability to support cell adhesion and division of NPs. Hence, this Fe-doped HA holds an immense potential as a bone repair material for osteoporosis, where targeted delivery of calcium is required as a vehicle for site-specific drug delivery [123]. 
Table 6. Different types of calcium-based nanotechnologies for treatment of bone tissue

\begin{tabular}{|c|c|c|c|}
\hline $\begin{array}{c}\text { Type of } \\
\text { Nanosystems }\end{array}$ & Nanocarriers & Drug loaded & Main features \\
\hline \multirow{3}{*}{$\begin{array}{l}\text { Calcium- } \\
\text { based }\end{array}$} & $\begin{array}{l}\text { CP-coated human MSCs by addition of bio- } \\
\text { functionalized HAP colloids [121] }\end{array}$ & Growth factors & - Promotion of cell differentiation \\
\hline & Plasmid DNA-loaded CP NPs [122] & DNA & $\begin{array}{ll}\text { - } & \text { Gene delivery } \\
\text { - } & \text { Odontogenic differentiation }\end{array}$ \\
\hline & HA crystal doped with $10 \% \mathrm{Fe}$ [123] & Iron & $\begin{array}{ll}\text { - } & \text { Controlled drug release } \\
\text { - } & \text { Antibacterial properties } \\
\text { - } & \text { Bioactivity }\end{array}$ \\
\hline
\end{tabular}

\subsection{Silica-based green nanotechnologies}

Silica-based ordered mesoporous materials have shown new properties as drug carriers, as well as in bone regeneration mechanism. These ordered materials can be loaded with various molecules that could be delivered in a controlled manner. Silica nanomaterials can react with the body fluids producing carbonated Nano apatite particles, which enable the regeneration of bone tissue [124-126].

As an example, Mann et al. developed a multifunctional drug delivery system, based on the combination of an E-selectin thioaptamer ligand (ESTA), conjugated to biocompatible porous silicon nanoparticles. This nanosystem was used in vitro as a delivery platform to provide imaging agents and growth factors, such as colony-stimulating factor (CSF), for the protection of bone marrow against chemotherapy and radiation [127]. Another example showed how ordered mesoporous silica was synthesized by a surfactant-assisted sol-gel process, with appropriate porosity, mineralization activity and adsorption/release of metronidazole. An antibiotic and antiprotozoal drug, metronidazole forms from mesoporous channels of silica, that were regulated using functional groups, chemically bonded with an outer silica surface. In vitro results confirmed the potential of the material as a drug carrier and bone substitute in bone disease. [128]. Similarly, Yao et al. developed mesoporous silicate nanoparticles incorporated in a 3D nanofibrous gelatin scaffold for dual-delivery of BMP2 and deferoxamine (DFO) - a hypoxia-mimetic drug that can trigger angiogenesis for bone tissue applications. In vitro data indicated 
that the nanostructure had the ability to control dual-release of DFO and BMP2 at a distinct release rate, while maintaining their angiogenic and osteogenic abilities, respectively [129].
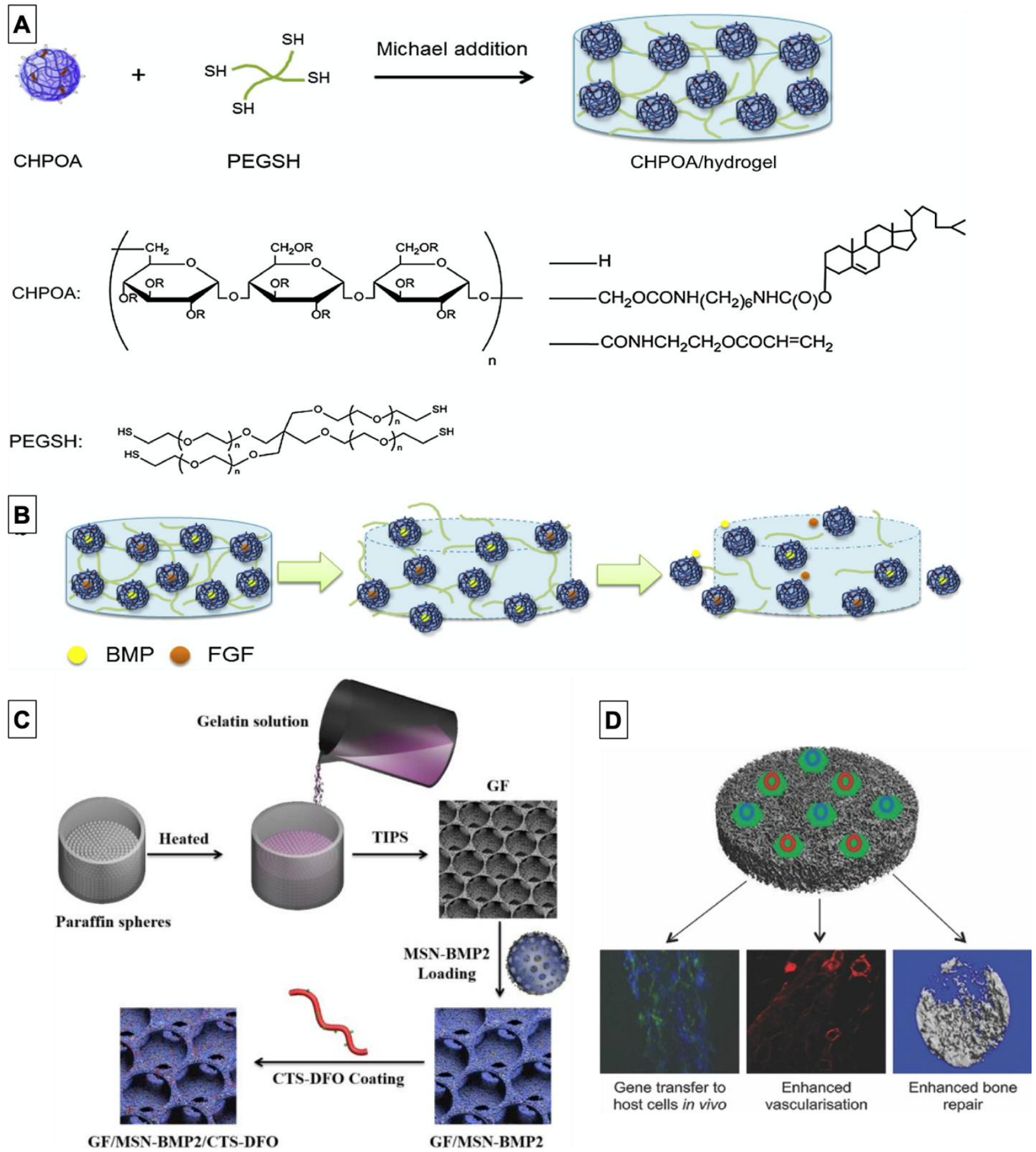

Figure 3.(A) Synthesis of the acryloyl group-modified cholesterol-bearing pullulan (CHPOA) nanogel and chemical structure of the CHPOA nanogel and PEGSH and (B) Schematic representation of the FGF18and BMP2-releasing from nanogels after the disintegration [110]; (C) Schematic illustration of synthesis 
procedure of 3D nanofibrous gelatin (GF) scaffold for dual-delivery of BMP2 and deferoxamine (DFO) using chitosan (CTS) and mesoporous silica nanoparticles (MSN) [129]; (D) Stem cell-mediated osteogenesis in vitro, in addition to increased vascularization and bone repair by host cells in vivo, is enhanced using all systems while the use of the nanohydroxyapatite vector to deliver both genes markedly enhances bone healing [119]. CHPOA = Cholesteryl-group and acryloyl group-bearing pullulan; PEGSH = Poly(ethylene glycol) methyl ether thiol; $\mathrm{BMP}=$ Bone morphogenic protein; $\mathrm{FGF}=$ Fibroblast growth factor; MSN = Mesoporous silica

\section{Conclusion}

The effective diagnosis and treatment of osteogenic bone disorders require novel methodologies to solve some of its main challenges. Nanotechnology-based drug delivery systems have proven to play an important role in the future. Despite the recent advances in the application of NMs as drug delivery systems, several drawbacks arise in terms of the production of carriers and the application for successful targeting. Consequently, the application of the 12 principles of green chemistry to nanotechnology is presented as a novel solution to overcome the main challenges of the current biomedical applications of NMs. From the use of biomolecules and mineral materials to the application of proteins as drug delivery carriers, these natural materials offer the possibility of a brighter future for the treatment of osteogenic disorders.

\section{Expert Opinion}

This review article is made as an attempt to show the potential of Green Nanotechnology as a suitable tool to solve universal problems in the biomedical field of drug delivery processes, with a particular focus on the treatment of osteogenic disorders and other bone diseases. As a consequence, a set of unique inorganic and organic biomaterials is presented as building blocks for the generation of drug delivery systems. The advances and research presented in this article have an impact in the real-world in terms of effectiveness, 
economy and drug utilization, where green nanotechnological-based nanomaterials show relevant improvements compared to physiochemically-produced nanostructures.

The use of organic biomolecules derived from natural sources, such as carbohydrates and proteins, offers the possibility to easily manipulate the features of the synthesized nanostructures, rendering different release profiles of the drugs, while achieving an easy and controlled targeting of the affected area. On the other hand, the employment of naturally existent elements in the human body with proliferative capability, such as CPs and silica, can be employed as tunable pieces for the production of suitable composites, and as platforms for the efficient drug delivery of molecules and drugs.

Furthermore, one of the key components of the use of green nanotechnology is that these nanomaterials are produced through straightforward, cost-effective and environmentally-friendly approaches, avoiding the production of toxic by-products. Comparatively, the traditional synthesis of nanomaterials often employs harmful reagents, and its reaction conditions are far from standard conditions. In addition, and more importantly, the use of biomolecules as raw materials in the production of nanoscale drug delivery systems confer them with an enhanced biocompatibility, compared to traditionally-synthesized nanoformulations, which often requires extensive functionalization steps, in order to make them suitable to contact different biological tissues, with an increase of time and expenses to find a suitable drug delivery system.

Despite of such enhancements in vitro, the successful applicability of the nanosystems finds clear challenges when applied in vivo, as it is inherent to other nanomaterials, especially in terms of an effective targeting and clearance from the organism. A main disadvantage in terms of the implementation into clinical and research practice of these green nanotechnological-based approaches is related to an extensive lack of knowledge (as it is common of a relatively novel field in terms of drug delivery applications for osteogenic disorders). In order to solve the aforementioned limitations, more research is needed, with a specialized aim in solving the heterogeneity of the production of these nanomaterials, which supposes a substantial weakness in the employment of biomolecules for the building of drug 
delivery systems. Different batches of the purification of these biomolecules unavoidably lead to different degrees of variations in terms of their chemical and physical features, hence rendering slightly different applicability. Therefore, more homogeneous purification techniques and methods to increase the purity of the raw materials, must be obtained before going deeper into the homogeneity of the applications. Subsequently, this limitation is delaying some of the hopeful (and much needed) advancements in the field.

Nevertheless, research has shown a tremendous potential, due to the wide variety of natural biomolecules and structures available to use as raw materials for the synthesis of drug delivery systems. Furthermore, there is no need of extensively modified structures, as slightly different formulations are already available to be used in nature. Therefore, the ultimate goal of the field is to be able to find a suitable set of compounds that are both easily obtained, purified, and manipulated, and the ones which present constant features in their application as drug delivery systems for osteogenic disorders. Currently, a few of these formulations are already well-studied and applied, such as chitosan or gelatin, which allow for a successful implementation of drug delivery approaches through different available morphological systems, like films, membranes, sponges, or composites. Therefore, utilizing the strong base of such successful research, similar protocols have been used to standardize and establish other molecules as suitable drug delivery systems, which undoubtedly will have an impact in the treatment, diagnosis, and healing of different bone disorders.

As a conclusion, there is a huge potential in the use of green nanotechnology as a tool to enhance the drug delivery of different molecules for the effective treatment of osteogenic disorders. However, more research has to be done in order to establish green-derived nanotechnologies as a biomedical tool in the field. 


\section{References}

[1] Docherty B. Skeletal system. Part one--bone structure. Nurs. Times [Internet]. [cited 2019 Jul 19];103:28-29. Available from: http://www.ncbi.nlm.nih.gov/pubmed/17319304.

[2] Frassica FJ, Inoue N, Virolainen P, et al. Skeletal system: biomechanical concepts and relationships to normal and abnormal conditions. Semin. Nucl. Med. [Internet]. 1997 [cited 2019 Jul 19];27:321-327. Available from: http://www.ncbi.nlm.nih.gov/pubmed/9364641.

[3] Raggatt LJ, Partridge NC. Cellular and molecular mechanisms of bone remodeling. J. Biol. Chem. [Internet]. 2010 [cited 2019 Jul 19];285:25103-25108. Available from: http://www.ncbi.nlm.nih.gov/pubmed/20501658.

[4] Rowe P, Sharma S. Physiology, Bone Remodeling [Internet]. StatPearls. StatPearls Publishing; 2019 [cited 2019 Jul 19]. Available from: http://www.ncbi.nlm.nih.gov/pubmed/29763038.

[5] US Department of Health and Human Services. Bone health and osteoporosis: a report of the Surgeon General. US Heal. Hum. Serv. [Internet]. 2004 [cited 2020 Jan 14];437. Available from: http://scholar.google.com/scholar?hl=en\&btnG=Search\&q=intitle:Bone+Health+and+Osteoporosi $\mathrm{s}+\mathrm{A}+$ Report+of+the+Surgeon+General\#0.

[6] Sinusas K. Osteoarthritis: diagnosis and treatment. Am. Fam. Physician [Internet]. 2012 [cited 2019 Jul 19];85:49-56. Available from: http://www.ncbi.nlm.nih.gov/pubmed/22230308.

[7] Chen D, Shen J, Zhao W, et al. Osteoarthritis: toward a comprehensive understanding of pathological mechanism. Bone Res. [Internet]. 2017 [cited 2019 Jul 19];5:16044. Available from: http://www.ncbi.nlm.nih.gov/pubmed/28149655.

[8] Rosen CJ. The Epidemiology and Pathogenesis of Osteoporosis [Internet]. Endotext. MDText.com, Inc.; 2000 [cited 2019 Jul 19]. Available from: http://www.ncbi.nlm.nih.gov/pubmed/25905357.

[9] Sözen T, Özış1k L, Başaran NÇ. An overview and management of osteoporosis. Eur. J. Rheumatol. [Internet]. 2017 [cited 2019 Jul 19];4:46-56. Available from: http://www.ncbi.nlm.nih.gov/pubmed/28293453.

[10] Fritz JM, McDonald JR. Osteomyelitis: approach to diagnosis and treatment. Phys. Sportsmed. [Internet]. 2008 [cited 2019 Jul 19];36:nihpa116823. Available from: http://www.ncbi.nlm.nih.gov/pubmed/19652694.

[11] Momodu II, Savaliya V. Osteomyelitis [Internet]. StatPearls. StatPearls Publishing; 2019 [cited 2019 Jul 19]. Available from: http://www.ncbi.nlm.nih.gov/pubmed/30335283.

[12] Durfee RA, Mohammed M, Luu HH. Review of Osteosarcoma and Current Management. Rheumatol. Ther. [Internet]. 2016 [cited 2019 Jul 19];3:221-243. Available from: http://www.ncbi.nlm.nih.gov/pubmed/27761754.

[13] Misaghi A, Goldin A, Awad M, et al. Osteosarcoma: a comprehensive review. SICOT-J [Internet]. 2018 [cited 2019 Jul 19];4:12. Available from: http://www.ncbi.nlm.nih.gov/pubmed/29629690.

[14] van Dijk FS, Cobben JM, Kariminejad A, et al. Osteogenesis Imperfecta: A Review with Clinical Examples. Mol. Syndromol. [Internet]. 2011 [cited 2019 Jul 19];2:1-20. Available from: 
http://www.ncbi.nlm.nih.gov/pubmed/22570641.

[15] Sam JE, Dharmalingam M. Osteogenesis Imperfecta. Indian J. Endocrinol. Metab. [Internet]. 2017 [cited 2019 Jul 19];21:903-908. Available from: http://www.ncbi.nlm.nih.gov/pubmed/29285457.

[16] Stapleton M, Sawamoto K, Alméciga-Díaz CJ, et al. Development of Bone Targeting Drugs. Int. J. Mol. Sci. 2017;18.

[17] Luhmann T, Germershaus O, Groll J, et al. Bone targeting for the treatment of osteoporosis. J. Control. Release. 2012;161:198-213.

[18] Carbone EJ, Rajpura K, Allen BN, et al. Osteotropic nanoscale drug delivery systems based on small molecule bone-targeting moieties. Nanomedicine Nanotechnology, Biol. Med. 2017;13:3747.

[19] Drake MT, Clarke BL, Khosla S. Bisphosphonates: mechanism of action and role in clinical practice. Mayo Clin. Proc. 2008;83:1032-1045.

[20] Heymann D. Bisphosphonates and bone diseases: past, present and future. Curr. Pharm. Des. 2010;16:2948-2949.

[21] Uludag H. Bisphosphonates as a Foundation of Drug Delivery to Bone. Curr. Pharm. Des. [Internet]. 2002 [cited 2019 Jul 2];8:1929-1944. Available from: http://www.eurekaselect.com/openurl/content.php?genre=article\&issn=1381$6128 \&$ volume $=8 \&$ issue $=21 \&$ spage $=1929$.

[22] Cole LE, Vargo-Gogola T, Roeder RK. Targeted delivery to bone and mineral deposits using bisphosphonate ligands. Adv. Drug Deliv. Rev. [Internet]. 2016 [cited 2019 Jul 2];99:12-27. Available from: https://www.sciencedirect.com/science/article/pii/S0169409X15002306.

[23] Billon-Chabaud A, Gouyette A, Merle C, et al. Development of bisphosphonates controlled delivery systems for bone implantation: influence of the formulation and process used on in vitro release. J. Mater. Sci. Mater. Med. [Internet]. 2010 [cited 2019 Jul 2];21:1599-1604. Available from: http://link.springer.com/10.1007/s10856-010-4012-x.

[24] Chopra I, Roberts M. Tetracycline antibiotics: mode of action, applications, molecular biology, and epidemiology of bacterial resistance. Microbiol. Mol. Biol. Rev. 2001;65:232-60 ; second page, table of contents.

[25] Demers P, Fraser D, Goldbloom RB, et al. Effects of tetracyclines on skeletal growth and dentition. A report by the Nutrition Committee of the Canadian Paediatric Society. Can. Med. Assoc. J. 1968;99:849-854.

[26] Payne JB, Golub LM. Using tetracyclines to treat osteoporotic/osteopenic bone loss: from the basic science laboratory to the clinic. Pharmacol. Res. 2011;63:121-129.

[27] Kanellakopoulou K, Giamarellos-Bourboulis EJ. Carrier Systems for the Local Delivery of Antibiotics in Bone Infections. Drugs [Internet]. 2000 [cited 2019 Jul 2];59:1223-1232. Available from: http://link.springer.com/10.2165/00003495-200059060-00003.

[28] Mombelli A, Feloutzis A, Bragger U, et al. Treatment of peri-implantitis by local delivery of tetracycline. Clinical, microbiological and radiological results. Clin. Oral Implants Res. [Internet]. 2001 [cited 2019 Jul 2];12:287-294. Available from: http://doi.wiley.com/10.1034/j.16000501.2001.012004287.x.

[29] Domingues ZR, Cortés ME, Gomes TA, et al. Bioactive glass as a drug delivery system of 
tetracycline and tetracycline associated with $\beta$-cyclodextrin. Biomaterials [Internet]. 2004 [cited 2019 Jul 2];25:327-333. Available from:

https://www.sciencedirect.com/science/article/pii/S0142961203005246.

[30] Wang H, Liu J, Tao S, et al. Tetracycline-grafted PLGA nanoparticles as bone-targeting drug delivery system. Int. J. Nanomedicine [Internet]. 2015 [cited 2019 Jul 2];10:5671-5685. Available from: http://www.ncbi.nlm.nih.gov/pubmed/26388691.

[31] Xie Y, Liu C, Huang H, et al. Bone-targeted delivery of simvastatin-loaded PEG-PLGA micelles conjugated with tetracycline for osteoporosis treatment. Drug Deliv. Transl. Res. [Internet]. 2018 [cited 2019 Jul 2];8:1090-1102. Available from: http://link.springer.com/10.1007/s13346-0180561-1.

[32] Takahashi-Nishioka T, Yokogawa K, Tomatsu S, et al. Targeted drug delivery to bone: pharmacokinetic and pharmacological properties of acidic oligopeptide-tagged drugs. Curr. Drug Discov. Technol. 2008;5:39-48.

[33] Sekido T, Sakura N, Higashi Y, et al. Novel drug delivery system to bone using acidic oligopeptide: pharmacokinetic characteristics and pharmacological potential. J. Drug Target. 2001;9:111-121.

[34] Sekido T, Sakura N, Higashi Y, et al. Novel Drug Delivery System to Bone Using Acidic Oligopeptide: Pharmacokinetic Characteristics and Pharmacological Potential. J. Drug Target. [Internet]. 2001 [cited 2019 Jul 2];9:111-121. Available from: http://www.tandfonline.com/doi/full/10.3109/10611860108997922.

[35] Ishizaki J, Waki Y, Takahashi-Nishioka T, et al. Selective drug delivery to bone using acidic oligopeptides. J. Bone Miner. Metab. [Internet]. 2009 [cited 2019 Jul 1];27:1-8. Available from: http://link.springer.com/10.1007/s00774-008-0004-z.

[36] Miyamoto K, Takahashi-Nishioka T, Yokogawa K, et al. Targeted Drug Delivery to Bone: Pharmacokinetic and Pharmacological Properties of Acidic Oligopeptide-Tagged Drugs. Curr. Drug Discov. Technol. [Internet]. 2008 [cited 2019 Jul 2];5:39-48. Available from: http://www.eurekaselect.com/openurl/content.php?genre=article\&issn=1570$1638 \&$ volume $=5 \&$ issue $=1 \&$ spage $=39$.

[37] Zhou J, Rossi J. Aptamers as targeted therapeutics: current potential and challenges. Nat. Rev. Drug Discov. [Internet]. 2017 [cited 2019 Jul 2];16:181-202. Available from: http://www.ncbi.nlm.nih.gov/pubmed/27807347.

[38] Newman MR, Benoit DS. Local and targeted drug delivery for bone regeneration. Curr. Opin. Biotechnol. [Internet]. 2016 [cited 2019 Jul 2];40:125-132. Available from: http://www.ncbi.nlm.nih.gov/pubmed/27064433.

[39] Chen L, He W, Jiang H, et al. In vivo SELEX of bone targeting aptamer in prostate cancer bone metastasis model. Int. J. Nanomedicine [Internet]. 2018 [cited 2019 Jul 2];Volume 14:149-159. Available from: https://www.dovepress.com/in-vivo-selex-of-bone-targeting-aptamer-in-prostatecancer-bone-metast-peer-reviewed-article-IJN.

[40] Feng X, McDonald JM. Disorders of bone remodeling. Annu. Rev. Pathol. [Internet]. 2011 [cited 2019 Jul 19];6:121-145. Available from: http://www.ncbi.nlm.nih.gov/pubmed/20936937.

[41] Xinluan W, Yuxiao L, Helena NH, et al. Systemic drug delivery systems for bone tissue regeneration- a mini review. Curr. Pharm. Des. [Internet]. 2015;21:1575-1583. Available from: http://www.ncbi.nlm.nih.gov/pubmed/25594406. 
[42] Alencastre I, Sousa D, Alves C, et al. Delivery of pharmaceutics to bone: nanotechnologies, highthroughput processing and in silico mathematical models. Eur. Cells Mater. 2016;31:355-381.

[43] Walmsley GG, McArdle A, Tevlin R, et al. Nanotechnology in bone tissue engineering. Nanomedicine [Internet]. 2015 [cited 2019 Jul 19];11:1253-1263. Available from: http://www.ncbi.nlm.nih.gov/pubmed/25791811.

[44] Yi H, Ur Rehman F, Zhao C, et al. Recent advances in nano scaffolds for bone repair. Bone Res. [Internet]. 2016 [cited 2019 Jul 19];4:16050. Available from: http://www.ncbi.nlm.nih.gov/pubmed/28018707.

[45] Mostafavi E, Soltantabar P. Nanotechnology and picotechnology: A new arena for translational medicine. Biomater. Transl. Med. 2019;191-212.

[46] Chun YW, Webster TJ. The role of nanomedicine in growing tissues. Ann. Biomed. Eng. 2009;

[47] Cheng H, Chawla A, Yang Y, et al. Development of nanomaterials for bone-targeted drug delivery. Drug Discov. Today [Internet]. 2017 [cited 2019 Jul 23];22:1336-1350. Available from: http://www.ncbi.nlm.nih.gov/pubmed/28487069.

[48] Maeda H. Macromolecular therapeutics in cancer treatment: The EPR effect and beyond. J. Control. Release [Internet]. 2012 [cited 2019 Jul 25];164:138-144. Available from: http://www.ncbi.nlm.nih.gov/pubmed/22595146.

[49] Busatto S, Pham A, Suh A, et al. Organotropic drug delivery: Synthetic nanoparticles and extracellular vesicles. Biomed. Microdevices. 2019;

[50] Barry M, Pearce H, Cross L, et al. Advances in Nanotechnology for the Treatment of Osteoporosis. Curr. Osteoporos. Rep. 2016.

[51] Jiang C, Jia J, Zhai S. Mechanistic Understanding of Toxicity from Nanocatalysts. Int. J. Mol. Sci. [Internet]. 2014 [cited 2019 Jul 16];15:13967-13992. Available from: http://www.ncbi.nlm.nih.gov/pubmed/25119861.

[52] Sportelli MC, Izzi M, Volpe A, et al. The Pros and Cons of the Use of Laser Ablation Synthesis for the Production of Silver Nano-Antimicrobials. Antibiot. (Basel, Switzerland) [Internet]. 2018 [cited 2019 Jul 16];7. Available from: http://www.ncbi.nlm.nih.gov/pubmed/30060553.

[53] Ali A, Zafar H, Zia M, et al. Synthesis, characterization, applications, and challenges of iron oxide nanoparticles. Nanotechnol. Sci. Appl. [Internet]. 2016 [cited 2019 Jul 16];9:49-67. Available from: http://www.ncbi.nlm.nih.gov/pubmed/27578966.

[54] Borm PJA, Robbins D, Haubold S, et al. The potential risks of nanomaterials: a review carried out for ECETOC. Part. Fibre Toxicol. [Internet]. 2006 [cited 2019 Jul 16];3:11. Available from: http://www.ncbi.nlm.nih.gov/pubmed/16907977.

[55] Smith WR, Hudson PW, Ponce BA, et al. Nanotechnology in orthopedics: A clinically oriented review. BMC Musculoskelet. Disord. 2018.

[56] Bose S, Tarafder S. Calcium phosphate ceramic systems in growth factor and drug delivery for bone tissue engineering: A review. Acta Biomater. 2012.

[57] Bosco R, Iafisco M, Tampieri A, et al. Hydroxyapatite nanocrystals functionalized with alendronate as bioactive components for bone implant coatings to decrease osteoclastic activity. Appl. Surf. Sci. 2015;

[58] Yi C, Liu D, Fong CC, et al. Gold nanoparticles promote osteogenic differentiation of 
mesenchymal stem cells through p38 MAPK pathway. ACS Nano. 2010;

[59] Ghosh P, Han G, De M, et al. Gold nanoparticles in delivery applications. Adv. Drug Deliv. Rev. 2008.

[60] Mehranfar S, Abdi Rad I, Mostafavi E, et al. The use of stromal vascular fraction (SVF), plateletrich plasma (PRP) and stem cells in the treatment of osteoarthritis: an overview of clinical trials. Artif. Cells, Nanomedicine, Biotechnol. 2019;47:882-890.

[61] Lee D, Heo DN, Kim HJ, et al. Inhibition of Osteoclast Differentiation and Bone Resorption by Bisphosphonate-conjugated Gold Nanoparticles. Sci. Rep. 2016;

[62] Behzadi S, Luther GA, Harris MB, et al. Nanomedicine for safe healing of bone trauma: Opportunities and challenges. Biomaterials. 2017.

[63] Yang L, Webster TJ. Nanotechnology controlled drug delivery for treating bone diseases. Expert Opin. Drug Deliv. 2009;

[64] Bose S, Banerjee D, Bandyopadhyay A. Introduction to Biomaterials and Devices for Bone Disorders. Mater. Devices Bone Disord. 2016.

[65] Mendonça G, Mendonça DBS, Aragão FJL, et al. Advancing dental implant surface technology From micron- to nanotopography. Biomaterials. 2008.

[66] Shen X, Ma P, Hu Y, et al. Alendronate-loaded hydroxyapatite-TiO2 nanotubes for improved bone formation in osteoporotic rabbits. J. Mater. Chem. B. 2016;

[67] Tran N, Webster TJ. Increased osteoblast functions in the presence of hydroxyapatite-coated iron oxide nanoparticles. Acta Biomater. 2011;

[68] Butoescu N, Seemayer CA, Foti M, et al. Dexamethasone-containing PLGA superparamagnetic microparticles as carriers for the local treatment of arthritis. Biomaterials. 2009;

[69] Kim MH, Na HK, Kim YK, et al. Facile synthesis of monodispersed mesoporous silica nanoparticles with ultralarge pores and their application in gene delivery. ACS Nano. 2011;

[70] Argyo C, Weiss V, Bräuchle C, et al. Multifunctional mesoporous silica nanoparticles as a universal platform for drug delivery. Chem. Mater. 2014.

[71] El-Fiqi A, Kim TH, Kim M, et al. Capacity of mesoporous bioactive glass nanoparticles to deliver therapeutic molecules. Nanoscale. 2012;

[72] Wu C, Chang J. Mesoporous bioactive glasses: Structure characteristics, drug/growth factor delivery and bone regeneration application. Interface Focus. 2012.

[73] Hu Y, Cai K, Luo Z, et al. Layer-by-layer assembly of $\beta$-estradiol loaded mesoporous silica nanoparticles on titanium substrates and its implication for bone homeostasis. Adv. Mater. 2010;

[74] Kose N, Çaylak R, Pekşen C, et al. Silver ion doped ceramic nano-powder coated nails prevent infection in open fractures: In vivo study. Injury. 2016;

[75] Medina-Cruz D, González MU, Tien-Street W, et al. Synergic antibacterial coatings combining titanium nanocolumns and tellurium nanorods. Nanomedicine Nanotechnology, Biol. Med. [Internet]. 2019 [cited 2019 Jul 25];17:36-46. Available from: http://www.ncbi.nlm.nih.gov/pubmed/30654187. ** (of considerable interest). Interesting example of the application of green nanomaterials for the enhancements of biomedical applications of implantable materials. 
[76] Wang G, Mostafa NZ, Incani V, et al. Bisphosphonate-decorated lipid nanoparticles designed as drug carriers for bone diseases. J. Biomed. Mater. Res. Part A [Internet]. 2012 [cited 2019 Jul 23];100A:684-693. Available from: http://www.ncbi.nlm.nih.gov/pubmed/22213565.

[77] Zhang P, Zhang Y, Gao M, et al. Dendrimer-assisted hydrophilic magnetic nanoparticles as sensitive substrates for rapid recognition and enhanced isolation of target tumor cells. Talanta. 2016;

[78] Akbarzadeh A, Khalilov R, Mostafavi E, et al. Role of dendrimers in advanced drug delivery and biomedical applications: a review. Exp. Oncol. [Internet]. 2018 [cited 2019 Jun 26];40:178183. Available from: http://www.ncbi.nlm.nih.gov/pubmed/30285011.

[79] Sun Y, Ye X, Cai M, et al. Osteoblast-Targeting-Peptide Modified Nanoparticle for siRNA/microRNA Delivery. ACS Nano. 2016;

[80] Huang L, Wang X, Cao H, et al. A bone-targeting delivery system carrying osteogenic phytomolecule icaritin prevents osteoporosis in mice. Biomaterials. 2018;

[81] Ayre WN, Birchall JC, Evans SL, et al. A novel liposomal drug delivery system for PMMA bone cements. J. Biomed. Mater. Res. - Part B Appl. Biomater. 2016;

[82] Riva R, Ragelle H, Des Rieux A, et al. Chitosan and chitosan derivatives in drug delivery and tissue engineering. Adv. Polym. Sci. 2011.

[83] Kalantari K, Afifi AM, Jahangirian H, et al. Biomedical applications of chitosan electrospun nanofibers as a green polymer - Review. Carbohydr. Polym. 2019.

[84] Gentile P, Nandagiri VK, Pabari R, et al. Influence of parathyroid hormone-loaded plga nanoparticles in porous scaffolds for bone regeneration. Int. J. Mol. Sci. 2015;

[85] $\mathrm{Gu} \mathrm{W}, \mathrm{Wu} \mathrm{C}$, Chen J, et al. Nanotechnology in the targeted drug delivery for bone diseases and bone regeneration. Int. J. Nanomedicine. 2013.

[86] Betancourt T, Byrne JD, Sunaryo N, et al. PEGylation strategies for active targeting of PLA/PLGA nanoparticles. J. Biomed. Mater. Res. - Part A. 2009;

[87] Kumari A, Yadav SK, Yadav SC. Biodegradable polymeric nanoparticles based drug delivery systems. Colloids Surfaces B Biointerfaces. 2010.

[88] Samadikhah HR, Majidi A, Nikkhah M, et al. Preparation, characterization, and efficient transfection of cationic liposomes and nanomagnetic cationic liposomes. Int. J. Nanomedicine [Internet]. 2011 [cited 2019 Jul 23];6:2275-2283. Available from: http://www.ncbi.nlm.nih.gov/pubmed/22072865.

[89] Tang J, Chen J-Y, Liu J, et al. Calcium phosphate embedded PLGA nanoparticles: A promising gene delivery vector with high gene loading and transfection efficiency. Int. J. Pharm. [Internet]. 2012 [cited 2019 Jul 23];431:210-221. Available from: http://www.ncbi.nlm.nih.gov/pubmed/22561795.

[90] Short AR, Koralla D, Deshmukh A, et al. Hydrogels That Allow and Facilitate Bone Repair, Remodeling, and Regeneration. J. Mater. Chem. B [Internet]. 2015 [cited 2019 Jul 23];3:78187830. Available from: http://www.ncbi.nlm.nih.gov/pubmed/26693013.

[91] Bai X, Gao M, Syed S, et al. Bioactive hydrogels for bone regeneration. Bioact. Mater. [Internet]. 2018 [cited 2019 Jul 23];3:401-417. Available from: https://www.sciencedirect.com/science/article/pii/S2452199X18300264. 
[92] Shin S-H, Purevdorj O, Castano O, et al. A short review: Recent advances in electrospinning for bone tissue regeneration. J. Tissue Eng. [Internet]. 2012 [cited 2019 Jul 23];3:2041731412443530. Available from: http://www.ncbi.nlm.nih.gov/pubmed/22511995.

[93] Nedjari S, Awaja F, Altankov G. Three Dimensional Honeycomb Patterned Fibrinogen Based Nanofibers Induce Substantial Osteogenic Response of Mesenchymal Stem Cells. Sci. Rep. [Internet]. 2017 [cited 2019 Jul 23];7:15947. Available from: http://www.nature.com/articles/s41598-017-15956-8.

[94] Waters R, Pacelli S, Maloney R, et al. Stem cell secretome-rich nanoclay hydrogel: A dual action therapy for cardiovascular regeneration. Nanoscale. 2016;

[95] Stander L, Theodore L. Environmental implications of nanotechnology--an update. Int. J. Environ. Res. Public Health [Internet]. 2011 [cited 2019 Jul 1];8:470-479. Available from: http://www.ncbi.nlm.nih.gov/pubmed/21556197. * (of interest). Overview of the use of nanotechnology in an environmentally-friendly approach.

[96] Anastas P, Eghbali N. Green chemistry: principles and practice. Chem. Soc. Rev. [Internet]. 2010 [cited 2019 Jul 25];39:301-312. Available from: http://www.ncbi.nlm.nih.gov/pubmed/20023854.

[97] Saratale RG, Karuppusamy I, Saratale GD, et al. A comprehensive review on green nanomaterials using biological systems: Recent perception and their future applications. Colloids Surfaces B Biointerfaces [Internet]. 2018 [cited 2019 Feb 21];170:20-35. Available from: http://www.ncbi.nlm.nih.gov/pubmed/29860217. *** (of considerable interest). Updated overview of the use of green nanomaterials in biological applications.

[98] de la Guardia M. The challenges of green nanotechnology. Bioimpacts [Internet]. 2014 [cited 2019 Feb 21];4:1-2. Available from: http://www.ncbi.nlm.nih.gov/pubmed/24790892.

[99] Medina Cruz D, Mi G, Webster TJ. Synthesis and characterization of biogenic selenium nanoparticles with antimicrobial properties made by Staphylococcus aureus, methicillin-resistant Staphylococcus aureus (MRSA), Escherichia coli, and Pseudomonas aeruginosa. J. Biomed. Mater. Res. Part A [Internet]. 2018 [cited 2019 Jan 26];106:1400-1412. Available from: http://www.ncbi.nlm.nih.gov/pubmed/29356322.

[100] Thivaharan V, Ramesh V, Raja S. Green Synthesis of Silver Nanoparticles for Biomedical and Environmental Applications. Green Met. Nanoparticles [Internet]. Hoboken, NJ, USA: John Wiley \& Sons, Inc.; 2018 [cited 2019 Jul 1]. p. 287-439. Available from: http://doi.wiley.com/10.1002/9781119418900.ch12.

[101] Das M, Chatterjee S. Green synthesis of metal/metal oxide nanoparticles toward biomedical applications: Boon or bane. Green Synth. Charact. Appl. Nanoparticles [Internet]. 2019 [cited 2019 Jul 1];265-301. Available from: https://www.sciencedirect.com/science/article/pii/B9780081025796000113.

[102] Lomelí-Marroquín D, Medina Cruz D, Nieto-Argüello A, et al. Starch-mediated synthesis of mono- and bimetallic silver/gold nanoparticles as antimicrobial and anticancer agents. Int. J. Nanomedicine [Internet]. 2019 [cited 2019 Jun 21];Volume 14:2171-2190. Available from: https://www.dovepress.com/starch-mediated-synthesis-of-mono--and-bimetallic-silvergoldnanoparti-peer-reviewed-article-IJN.

[103] Liu Y, Deng F, Zhang L, et al. Sustained dual release of placental growth factor-2 and bone morphogenic protein-2 from heparin-based nanocomplexes for direct osteogenesis. Int. J. Nanomedicine [Internet]. 2016 [cited 2019 Jun 28];11:1147. Available from: http://www.ncbi.nlm.nih.gov/pubmed/27042064. 
[104] Kim SE, Jeon O, Lee JB, et al. Enhancement of ectopic bone formation by bone morphogenetic protein-2 delivery using heparin-conjugated PLGA nanoparticles with transplantation of bone marrow-derived mesenchymal stem cells. J. Biomed. Sci. [Internet]. 2008 [cited 2019 Jun 28];15:771-777. Available from: http://www.springerlink.com/index/10.1007/s11373-008-9277-4.

[105] Lee B-S, Lee C-C, Wang Y-P, et al. Controlled-release of tetracycline and lovastatin by poly(D,Llactide-co-glycolide acid)-chitosan nanoparticles enhances periodontal regeneration in dogs. Int. J. Nanomedicine [Internet]. 2016 [cited 2019 Jun 28];11:285-297. Available from: http://www.ncbi.nlm.nih.gov/pubmed/26848264.

[106] Valente JFA, Gaspar VM, Antunes BP, et al. Microencapsulated chitosan-dextran sulfate nanoparticles for controled delivery of bioactive molecules and cells in bone regeneration. Polymer (Guildf). [Internet]. 2013 [cited 2019 Jun 28];54:5-15. Available from: https://www.sciencedirect.com/science/article/pii/S0032386112008889.

[107] Gaur S, Wen Y, Song JH, et al. Chitosan nanoparticle-mediated delivery of miRNA-34a decreases prostate tumor growth in the bone and its expression induces non-canonical autophagy. Oncotarget [Internet]. 2015 [cited 2019 Jun 28];6:29161-29177. Available from:

http://www.ncbi.nlm.nih.gov/pubmed/26313360.

[108] Lim TY, Wang W, Shi Z, et al. Human bone marrow-derived mesenchymal stem cells and osteoblast differentiation on titanium with surface-grafted chitosan and immobilized bone morphogenetic protein-2. J. Mater. Sci. Mater. Med. [Internet]. 2009 [cited 2019 Jun 28];20:1-10. Available from: http://www.ncbi.nlm.nih.gov/pubmed/18651113.

[109] Shi Z, Neoh KG, Kang ET, et al. Surface Functionalization of Titanium with Carboxymethyl Chitosan and Immobilized Bone Morphogenetic Protein-2 for Enhanced Osseointegration. Biomacromolecules [Internet]. 2009 [cited 2019 Jun 28];10:1603-1611. Available from: https://pubs.acs.org/doi/10.1021/bm900203w.

[110] Fujioka-Kobayashi M, Ota MS, Shimoda A, et al. Cholesteryl group- and acryloyl group-bearing pullulan nanogel to deliver BMP2 and FGF18 for bone tissue engineering. Biomaterials [Internet]. 2012 [cited 2019 Jun 28];33:7613-7620. Available from: https://www.sciencedirect.com/science/article/pii/S0142961212007259.

[111] Dyondi D, Webster TJ, Banerjee R. A nanoparticulate injectable hydrogel as a tissue engineering scaffold for multiple growth factor delivery for bone regeneration. Int. J. Nanomedicine [Internet]. 2013 [cited 2019 Jun 28];8:47-59. Available from: http://www.ncbi.nlm.nih.gov/pubmed/23293519.

[112] Harris LG, Richards RG. Staphylococcus aureus adhesion to different treated titanium surfaces. J. Mater. Sci. Mater. Med. [Internet]. 2004 [cited 2019 Jul 25];15:311-314. Available from: http://www.ncbi.nlm.nih.gov/pubmed/15332591.

[113] Foster TJ. The Staphylococcus aureus "superbug.” J. Clin. Invest. [Internet]. 2004 [cited 2019 Jul 25];114:1693-1696. Available from: http://www.ncbi.nlm.nih.gov/pubmed/15599392.

[114] Lee KY, Mooney DJ. Alginate: properties and biomedical applications. Prog. Polym. Sci. [Internet]. 2012 [cited 2019 Jun 28];37:106-126. Available from: http://www.ncbi.nlm.nih.gov/pubmed/22125349.

[115] Gonzalez-Fernandez T, Tierney EG, Cunniffe GM, et al. Gene Delivery of TGF- $\beta 3$ and BMP2 in an MSC-Laden Alginate Hydrogel for Articular Cartilage and Endochondral Bone Tissue Engineering. Tissue Eng. Part A [Internet]. 2016 [cited 2019 Jun 28];22:776-787. Available from: https://www.liebertpub.com/doi/10.1089/ten.tea.2015.0576. 
[116] Nishida A, Yamada M, Kanazawa T, et al. Sustained-release of protein from biodegradable sericin film, gel and sponge. Int. J. Pharm. [Internet]. 2011 [cited 2019 Jun 28];407:44-52. Available from: https://www.sciencedirect.com/science/article/pii/S0378517311000202. * (of interest). Interesting and complete example of the application of sustained released of biomolecules from film, gel and sponges.

[117] Nishida A, Naganuma T, Kanazawa T, et al. The characterization of protein release from sericin film in the presence of an enzyme: Towards fibroblast growth factor-2 delivery. Int. J. Pharm. [Internet]. 2011 [cited 2019 Jun 28];414:193-202. Available from: https://www.sciencedirect.com/science/article/pii/S0378517311004637.

[118] Pankongadisak P, Suwantong O. The potential use of thermosensitive chitosan/silk sericin hydrogels loaded with longan seed extract for bone tissue engineering. RSC Adv. 2018;8:40219 40231.

[119] Curtin CM, Tierney EG, McSorley K, et al. Combinatorial Gene Therapy Accelerates Bone Regeneration: Non-Viral Dual Delivery of VEGF and BMP2 in a Collagen-Nanohydroxyapatite Scaffold. Adv. Healthc. Mater. [Internet]. 2015 [cited 2019 Jun 28];4:223-227. Available from: http://doi.wiley.com/10.1002/adhm.201400397.

[120] Raina DB, Larsson D, Mrkonjic F, et al. Gelatin- hydroxyapatite- calcium sulphate based biomaterial for long term sustained delivery of bone morphogenic protein-2 and zoledronic acid for increased bone formation: In-vitro and in-vivo carrier properties. J. Control. Release [Internet]. 2018 [cited 2019 Jun 28];272:83-96. Available from: https://www.sciencedirect.com/science/article/pii/S0168365918300051.

[121] Gonzalez-McQuire R, Green DW, Partridge KA, et al. Coating of Human Mesenchymal Cells in 3D Culture with Bioinorganic Nanoparticles Promotes Osteoblastic Differentiation and Gene Transfection. Adv. Mater. [Internet]. 2007 [cited 2019 Jun 28];19:2236-2240. Available from: http://doi.wiley.com/10.1002/adma.200602770.

[122] Yang X, Walboomers XF, van den Dolder J, et al. Non-Viral Bone Morphogenetic Protein 2 Transfection of Rat Dental Pulp Stem Cells Using Calcium Phosphate Nanoparticles as Carriers. Tissue Eng. Part A [Internet]. 2008 [cited 2019 Jun 28];14:71-81. Available from: https://www.liebertpub.com/doi/10.1089/ten.a.2007.0102.

[123] Sheikh L, Sinha S, Singhababu YN, et al. Traversing the profile of biomimetically nanoengineered iron substituted hydroxyapatite: synthesis, characterization, property evaluation, and drug release modeling. RSC Adv. [Internet]. 2018 [cited 2019 Jun 28];8:19389-19401. Available from: http://xlink.rsc.org/?DOI=C8RA01539B.

[124] Slowing II, Vivero-Escoto JL, Wu C-W, et al. Mesoporous silica nanoparticles as controlled release drug delivery and gene transfection carriers. Adv. Drug Deliv. Rev. [Internet]. 2008 [cited 2019 Jun 28];60:1278-1288. Available from: https://www.sciencedirect.com/science/article/pii/S0169409X08000951.

[125] Vallet-Regí M. Ordered Mesoporous Materials in the Context of Drug Delivery Systems and Bone Tissue Engineering. Chem. - A Eur. J. [Internet]. 2006 [cited 2019 Jun 28];12:5934-5943. Available from: http://doi.wiley.com/10.1002/chem.200600226.

[126] Vallet-Regí M, Balas F, Colilla M, et al. Bone-regenerative bioceramic implants with drug and protein controlled delivery capability. Prog. Solid State Chem. [Internet]. 2008 [cited 2019 Jun 28];36:163-191. Available from:

https://www.sciencedirect.com/science/article/pii/S0079678607000684\#bib68. 
[127] Mann AP, Tanaka T, Somasunderam A, et al. E-Selectin-Targeted Porous Silicon Particle for Nanoparticle Delivery to the Bone Marrow. Adv. Mater. [Internet]. 2011 [cited 2019 Jun 28];23:H278-H282. Available from: http://doi.wiley.com/10.1002/adma.201101541.

[128] Czarnobaj K, Prokopowicz M, Greber K, et al. Use of Materials Based on Polymeric Silica as Bone-Targeted Drug Delivery Systems for Metronidazole. Int. J. Mol. Sci. [Internet]. 2019 [cited 2019 Jun 28];20:1311. Available from: https://www.mdpi.com/1422-0067/20/6/1311.

[129] Yao Q, Liu Y, Selvaratnam B, et al. Mesoporous silicate nanoparticles/3D nanofibrous scaffoldmediated dual-drug delivery for bone tissue engineering. J. Control. Release [Internet]. 2018 [cited 2019 Jun 28];279:69-78. Available from:

https://www.sciencedirect.com/science/article/pii/S0168365918301937. 
